Науковий вісник Ужгородського університету

Серія Біологія, Випуск 49 (2020): 7-35

(C) Бесеганич I.В., Гасинець Я.С., Кіш Р.Я., Сойма А.Д.,

DOI: $10.24144 / 1998-6475.2020 .49 .7-35$

Вакерич М.M. 2020

\title{
ПАРКИ ТА СКВЕРИ ІСТОРИЧНОГО МІКРОРАЙОНУ «МАЛИЙ ГАЛАГОВ» М. УЖГОРОДА
}

\author{
I.В. Бесеганич ${ }^{1}$, Я.С. Гасинець ${ }^{1}$, Р.Я. Кіш ${ }^{1}$, А.Д. Сойма ${ }^{1}$, М.М. Вакерич ${ }^{2}$
}

Parks and park squares of the historical urban district "Malyi Galagov" of Uzhhorod city. - Besehanych I., Hasynets Ya., Kish R., Soyma A., Vakerych M. - The publication continues the series of researches of green plantations of Uzhhorod, their assortment and modern composition. It's the second final part of the work on tree and shrub species in the historic urban district "Malyi Galagov" in Uzhhorod city. Analysis of parks' green areas, gardens, parterre and embankment in the urban district is presented in the paper. There are currently nine parks and park squares within the district. At the time of its foundation, seven of them date back to the period when Transcarpathia became part of the Czechoslovak Republic (1919-1939), Laudon's Arboretum is founded during Austro-Hungarian times, and one of them was created in the Soviet period. The history of creation of parks and squares is considered, changes and stages of their reconstruction during the last century are covered. The modern species, varieties and quantitative composition, the ratio of introduced and aboriginal species of tree and shrub plantations of each park and square are analyzed in detail, their general condition is assessed and characterized. Special attention is paid to the oldest park in the district and one of the oldest in Uzhhorod. It's the Laudon's arboretum that was laid in 1886, a saved fragment of which is a park-memorial of art landscape now. The history of the park, the dynamics of changes in its area and range over the centuries is covered. The current state of plantations reflects, in particular, the height and diameter of the trunk in all saved tree species of the arboretum.

Key words: green plantations, parks, park squares, inventory, dendroflora, aboriginal and introduced species, taxonomic analysis, Uzhhorod, Transcarpathia

Addresses: 1 - Department of Botany, Uzhhorod National University, Voloshyna str., 32, Uzhhorod, Ukraine; e-mail: hasinetsss@ukr.net

2 - Department of Genetics, Plant Physiology and Microbiology, Uzhhorod National University, Voloshyna str., 32, Uzhhorod, Ukraine, e-mail: mykhailo.vakerich@uzhnu.edu.ua

Парки та сквери історичного мікрорайону «Малий Галатов» м. Уэсгорода. - Бесеганич І.В., Гасинець Я.С., Кіш Р.Я., Сойма А.Д., Вакерич М.М. - Публікація продовжує ичкл досліджень зелених насаджень м Ужгорода, їхній асортимент та сучасний склад $i$ є другою завершальною частиною роботи, присвяченою деревним і чагарниковим породам історичного мікрорайону «Малий Галагов». У роботі представлено аналіз зелених насаджень скверів, парків, партеру та набережної в мікрорайоні. На теперішній час у межах мікрорайону нараховується дев'ять парків і скверів. За часом створення сім із них відноситься до періоду входження Закарпаття до складу Чехословаџької республіки (1919-1939), дендропарк Лаудона - до австроугорських часів, один - радянського періоду. Розглянуто історію створення парків і скверів, відбиті зміни та етапи їх реконструкиії впродовж сторіччя. Детально проаналізований сучасний видовий, сортовий $і$ кількісний склад, співвідношення інтродукованих та аборигенних видів деревно-чагарникових насаджень кожного парку $i$ скверу, виконано оцінку та охарактеризовано їхній загальний стан. Особлива увага зосереджена на найстарішому парку мікрорайону та одному з найбільш давніх в Ужгороді - закладеного ще у 1886 р. дендросаду Лаудона, збережений фрагмент якого сьогодні є парком-пам яткою садово-паркового мистеитвв місчевого значення. Висвітлено історію закладання парку, динаміку зміни його площі та асортименту впродовж сторіччя, відображений сучасний стан насаджень, зокрема, вказані висота та діаметр стовбура в усіх збережених деревних видів дендросаду.

Ключові слова: зелені насадження, парки, сквери, інвентаризація, дендрофлора, аборигенні та інтродуковані види, Ужгород, Закарпаття

Адреси: 1 - кафедра ботаніки, Ужгородський національний університет, вул. А. Волошина, 32, м. Ужгород, Україна, e-mail: hasinetsss@ukr.net

2 - кафедра генетики, фізіології рослин і мікробіології, Ужгородський національний університет, вул. A. Волошина, 32, м. Ужгород, Украӥна, e-mail: mykhailo.vakerich@uzhnu.edu.иа 


\section{Вступ}

Публікація продовжує цикл досліджень зелених насаджень м. Ужгорода, їхній асортимент та сучасний склад i $\epsilon$ наступною роботою, присвяченою деревним і чагарниковим породам історичного мікрорайону «Малий Галагов» (Hasynets et al. 2017; Besehanych et. al 2020). У попередній публікації «Деревно-чагарникові насадження мікрорайону «Малий Галагов» м. Ужгорода - історія формування та сучасний стан» (Besehanych et al. 2020) подані узагальнені дані про сучасний видовий і сортовий склад дерев і чагарників мікрорайону загалом, а також виконані оцінка та аналіз зелених насаджень його вулиць. 3 метою здійснити історичний зріз та зафіксувати сучасний стан зелених насаджень мікрорайону, зокрема, їхній видовий, сортовий склад та якісний стан, у цій роботі, що $\epsilon$ продовженням попередньої статті, поставлені завдання виконати інвентаризацію і детально по окремо розглянути деревно-чагарникові насадження скверів та парків мікрорайону. Використаний матеріал та застосована аналогічна методика, яка описана у вищезгаданій публікації. Більш детальні дані про походження видів також наведені $\mathrm{y}$ зведеній таблиці в тій же роботі.

\section{Результати досліджень}

На теперішній час у межах мікрорайону «Малий Галагов» нараховується дев'ять парків і скверів. За часом створення сім із них відноситься до періоду входження Закарпаття до складу Чехословацької республіки (19191939), дендропарк Лаудона - до австроугорських часів, один - радянського періоду.

\section{Дендросад Лаудона (інші назви:} дендропарк Лаудона, арборетум, дендрарій).

Найстарішим парком мікрорайону «Малий Галагов» є дендросад Лаудона, що був закладений у 1886 p. (Terletskyi at al. 1985). Цей парк був розташований позаду родинного будинку Лаудонів (нині будинок №27 на вулиці Собранецькій) й тягнувся вниз по схилу до сучасної площі Олександра Пушкіна, включаючи і сучасну територію міської дитячої лікарні. На той час, наприкінці XIX ст., на схилі позаду будинку до самого русла Малого Ужа (який впадав у р. Уж у районі сучасного пам'ятника Олександру Пушкіну) не було жодних будівель (Рис. 1).

Іштван Лаудон (ужгородський педагог i натураліст, доктор Ужгородської Королівської католицької гімназії) разом з колегою викупив цю ділянку, на якій планували висаджувати різні екзотичні рослини, у міського магістрату.

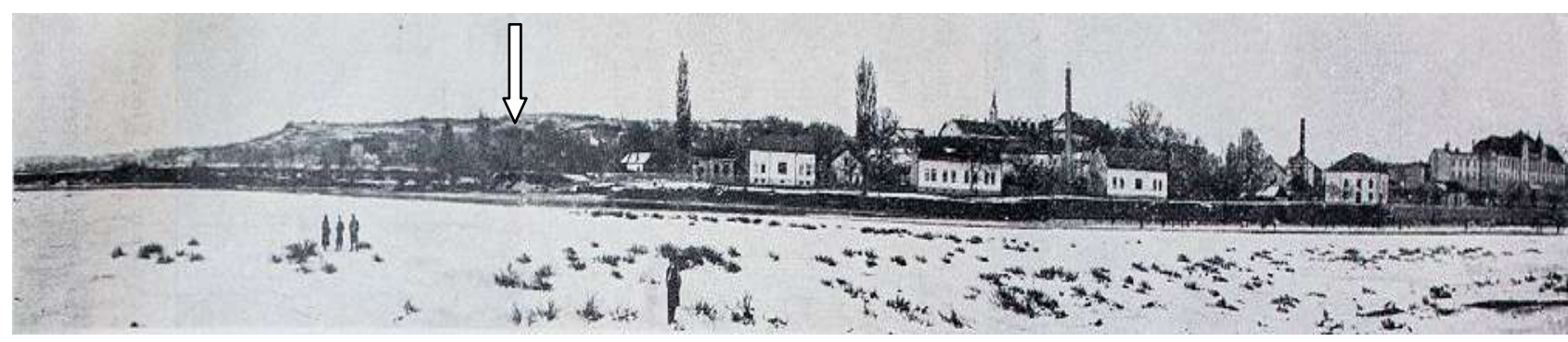

Рис. 1. Малий Галагов до забудови $(1920$ р.). Стрілкою вказано дендропарк Лаудона (https://www.facebook.com/uzhhorod.modernism/)

Fig. 1. Malyi Galagov before building (1920). The arrow indicates the Laudon's Arboretum (https://www.facebook.com/uzhhorod.modernism/)

За переказами старожилів будинку I. Лаудона сім’і Дюлай, за парком доглядав професійний садівник, який мешкав на нижньому поверсі згаданого будинку. За даними публікацій (Fodor 1951; 1956; Komendar 1990) та спогадами старожилів, парк налічував близько двох сотень екзотів. У вихідні він був відкритий для вільного відвідування, за що мешканці Ужгорода любили i поважали $\mathrm{I}$. Лаудона. Творіння Лаудона вважалося одним із найкращих молодих парків Австро-Угорщини. Наприкінці XIX ст. Лаудон отримав сертифікат від Віденської імператорської академії про те, що є власником одного 3 найкращих парків у всій Австро-Угорській імперії (Bilanych 2012).

При формуванні вулиць нового кварталу «Малий Галагов» цілісність парку була порушена і значна його частина була вилучена. Спочатку була забудована нижня ділянка, що прилягала до берега Ужа (Рис. 2, 3), пізніше, через прокладання сучасної вулиці Ференца Ракоці, територія парку, яка збереглася, була роз'єднана на два фрагменти. Одна частина залишилася при житловому будинку Лаудона, на іншій побудували дитячу лікарню. 


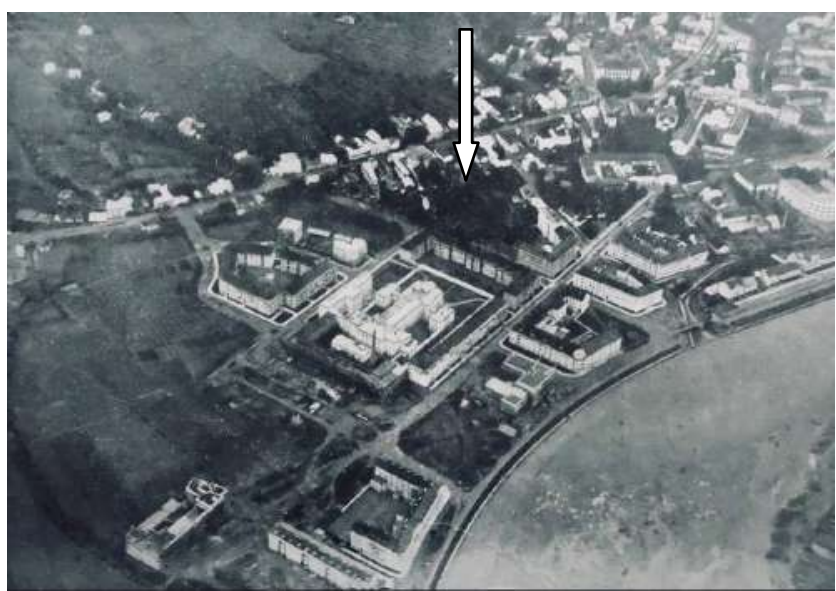

Рис. 2. Мікрорайон «Малий Галагов» на стадії забудови. Аерознімок 1931 року. У центральній частині - дендропарк Лаудона

(https://www.facebook.com/transcarpathian.heritage)

Fig. 2. Malyi Galagov during building stage. Aerial photopicture of 1931. Here is the Laudon's Arboretum in the central part

(https://www.facebook.com/transcarpathian.heritage)

У радянські часи ще одна частина парку була знищена для зведення багатоквартирного житлового будинку та кафе. Майже до кінця 80$\mathrm{x}$ років XX ст. зберігалася ділянка дендропарку

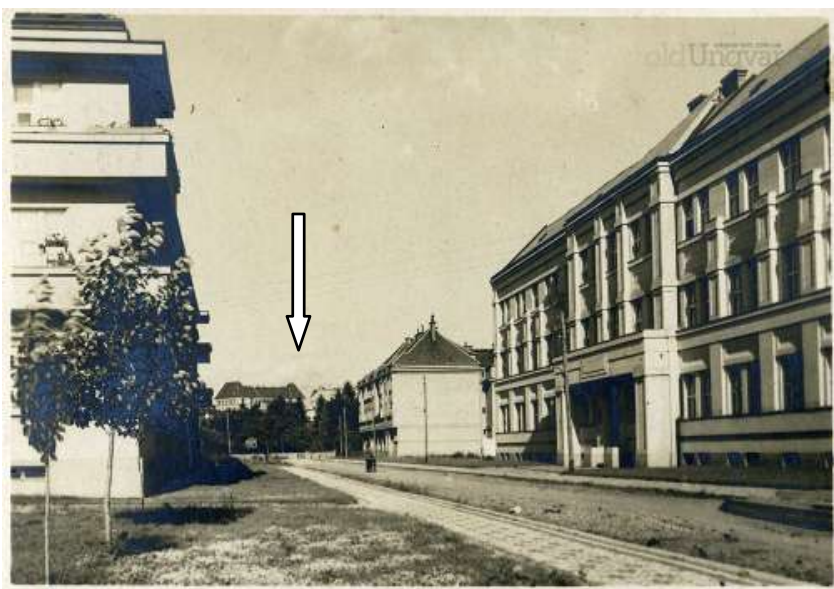

Рис. 3. Вулиця А. Швегли (1925-1927) (сучасна вул. Ференца Ракоці). На задньому плані дендропарк Лаудона

(https://www.facebook.com/transcarpathian.heritage)

Fig. 3. A. Shvehly street (1925-1927) (Ferentsa Rakotsi street now). The Laudon's Arboretum is in the back plan

(https://www.facebook.com/transcarpathian.heritage)

від будинку на вул. Собранецькій до вул. Ференца Ракоці. Тут були сходи, лавиці, фонтан (Рис. 4). Після розбудови приватного кафе і ця ділянка була знищена.

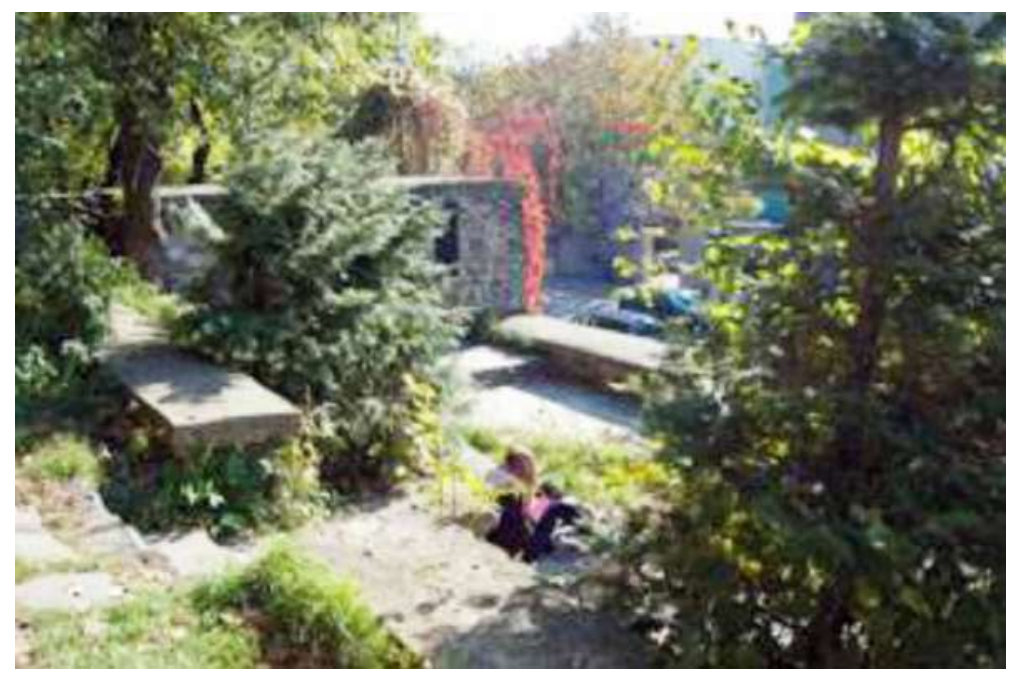

Рис. 4. Ділянка дендропарку Лаудона, що прилягала до будинку №27 на вулиці Собранецькій (https://karpatnews.in.ua/news/100215-shtrykhy-z-istorii-uzhhoroda.htm)

Fig. 4. The part of the Laudon's Arboretum adjacent to the house №27 on the Sobranetska street (https://karpatnews.in.ua/news/100215-shtrykhy-z-istorii-uzhhoroda.htm)

Асортимент дендропарку складався як із різних форм місцевих видів, так і екзотичних. Як відмічає С.С. Фодор (Fodor 1951) у 40-х роках минулого століття в парку Лаудона (зокрема на ділянці біля дитячої лікарні) ще нараховувалось 30 видів екзотичних рослин (в тому числі п'ять американських видів дуба, декілька видів ялини, сосни).

Для ділянки, що прилягала до будинку Лаудона, С.С. Фодор (Fodor 1956) наводить 
наступні види: шість видів голонасінних ялина європейська (Picea abies) та іiі плакуча форма (Picea abies f. inversa), гінкго дволопатеве (Ginkgo biloba), кипарисовик Лавсона (Chamaecyparis lawsoniana), широкогілочник східний (Platycladus orientalis), ялівець віргінський (Juniperus virginiana L.), тис ягідний (Taxus baccata) та три види дуба екзотичний дуб червоний (Quercus rubra) і два аборигенних - Q. petraea f. mespilifolia (3 довгастими слабохвилястими листками, що нагадують мушмулу) та дві форми дуба звичайного - строкатолиста $Q$. robur f. variegata й золотиста $Q$. robur f. aurea.

На нижній ділянці парку з аборигенних видів були представлені: сосна звичайна (Pinus sylvestris), бук звичайний форма рожевооблямована (Fagus sylvatica f. rosea-marginata) 3 пурпуровими, неправильними світло-рожевими краями листками, в культурі з 1888 року (тобто нові форми і сорти майже одразу потрапляли до парку), клен-явір (Acer pseudoplatanus f. variegata) (форма 3 строкатими листками), клокичка периста (Staphylea pinnata L.) аборигенний дуже рідкісний вид (на Закарпатті відомі поодинокі локалітети), що занесений до Червоної книги України (Chervona ... 2009), різні форми берези повислої (Betula pendula) та дуба звичайного. Екзотичні рослини, що росли на території дендропарку, характеризувалися різноманітністю життєвих форм, походженням, розмірами та виглядом: сосна австрійська (Pinus austriaca Hüll.), павловнія пухната (Paulownia tomentosa (Thunb.) Steud.), клен ясенолистий "Одессанум" (Acer negundo f. odessanum) (форма 3 жовто-зеленими листками), горобинник горобинолистий (Sorbaria sorbifolia (L.) А. Br.) 3 Азії, кельрейтерія волотиста або мильне дерево (Koelreuteria paniculata Laxm.) невелике дерево китайсько-японського походження, яке наприкінці літа прикрашають золоті волоті квітів, а незвичайні декоративні плоди нагадують паперові ліхтарики, магнолія Суланжа (Magnolia soulangeana f. amabilis) 3 блідо-рожевими квітками, що до сих пір росте на території дендропарку, бундук дводомний (Gymnocladus dioica (L.) C. Koch.) північноамериканське дерево $з$ листками, що пізно розпускаються i рано опадають, у спекотні дні повертаються «на ребро» та велетенськими бобами (до 25 см) 3 дуже твердим насінням; виткі рослини - ломиніс альпійський (Atragene alpina L.) - ліана до 1-2 м заввишки та ломиніс фіолетовий (Clematis viticella L.) - кущоподібна ліана до 4 м; кущі різні види спірей (Spiraea salicifolia L., $S$. japonica), самшит вічнозелений (Buxus sempervirens $\mathrm{f}$. suffuruticosa argentea-marginata). Окремо відмітимо болотний кипарис (Taxodium distichum) - вид, що трапляється в заболочених лісах на південному сході Північної Америки та для якого характерна наявність дихальних коренів, які ростуть вертикально вверх для забезпечення дихання на перезволожених грунтах. Для того, щоб створити умови, максимально наближені до природних, до дерев болотного кипарису були підведені труби, якими подавалася вода.

Згідно 3 проєктом «Комплесной зеленой зоны г. Ужгорода» (Kompleksnaja ... 1982) асортимент рослин у саді Лаудона на той період був представлений 42 видами i формами рослин. У документі вказувалось, що всі рослини добре збереглись і знаходяться у стані найбільшого розквіту.

Сьогодні від парку залишилися окремі дерева, розкидані по дворах, садах, вулицях району «Малий Галагов»: дуб звичайний i жіночий екземпляр гінкго дволопатевого у дворі буд. № 27 на вул. Собранецькій (екземпляр сосни віргінської (Pinus virginiana Mill.) старої посадки, що ріс у дворі, був знищений мешканцем будинку в 2017 році); кедр річковий (Calocedrus decurrens (Torr.) Florin) та кипарисовик Лавсона на вул. Ференца Ракоці біля кафе-кондитерської «Folks», церцис європейський (Cercis siliquastrum) на вул. Крилова (Рис. 5).

Найбільший фрагмент дендросаду зберігся поблизу дитячої лікарні (Рис. 5). Ділянка оголошена парком-пам яткою садовопаркового мистецтва місцевого значення «Сквер міської дитячої клінічної лікарні» (Дендросад Лаудона) (рішення ОВК №243 від 25.07 .1972 р.). Біля дендросаду встановлено інформаційне табло. Площа паркової зони становить 0,1423 га (загальна площа 0,2178 га). Зараз у парковій зоні збереглося 10 деревних видів та форм:

- туя складчаста або т. велетенська (Thuja plicata), висаджена у 1906 році, висотою 25 м та 83,7 см у діаметрі;

- сосна австрійська або с. чорна (Pinus austriaca), висота - 22,8 м, діаметр 80 см;

- гінкго дволопатеве (Ginkgo biloba) вважається найстаршим деревом гінкго в Україні (Lypa 1956; Fodor et al 1982), висота 24 м, діаметр 82 см;

- таксодій дворядний або болотний кипарис (Taxodium distichum), висота - 23,6 м, діаметр 108,3 см (Рис. 6); 
- бук лісовий (Fagus sylvatica), висота 20,6 м, діаметр 107,6 см;

- магнолія Суланжа (Magnolia $x$ soulangeana), висота - 7,8 м, діаметр $37 \mathrm{~cm}$ (Рис. 7);

- тис ягідний (Taxus baccata), висота $6 \mathrm{~m}$

- криптомерія японська (Cryptomeria japonica), висаджена у 1956 році, висота - 17,6 м, діаметр 39 см;
- тсуга канадська (Tsuga canadensis), висаджена у 2017 році (на жаль, у 2005 році екземпляр тсуги канадської, що ріс у саду Лаудона, у результаті суховершинення загинув (дерево має м`яку та крихку деревину, через що на батьківщині американці називають тсугу «hemlock», що означає «слабкий удар»);

- кипарисовик Лавсона (Chamaecyparis lawsoniana), висаджений у 2017 році, як і тсуга канадська - подарунок Адальберта Рішка.

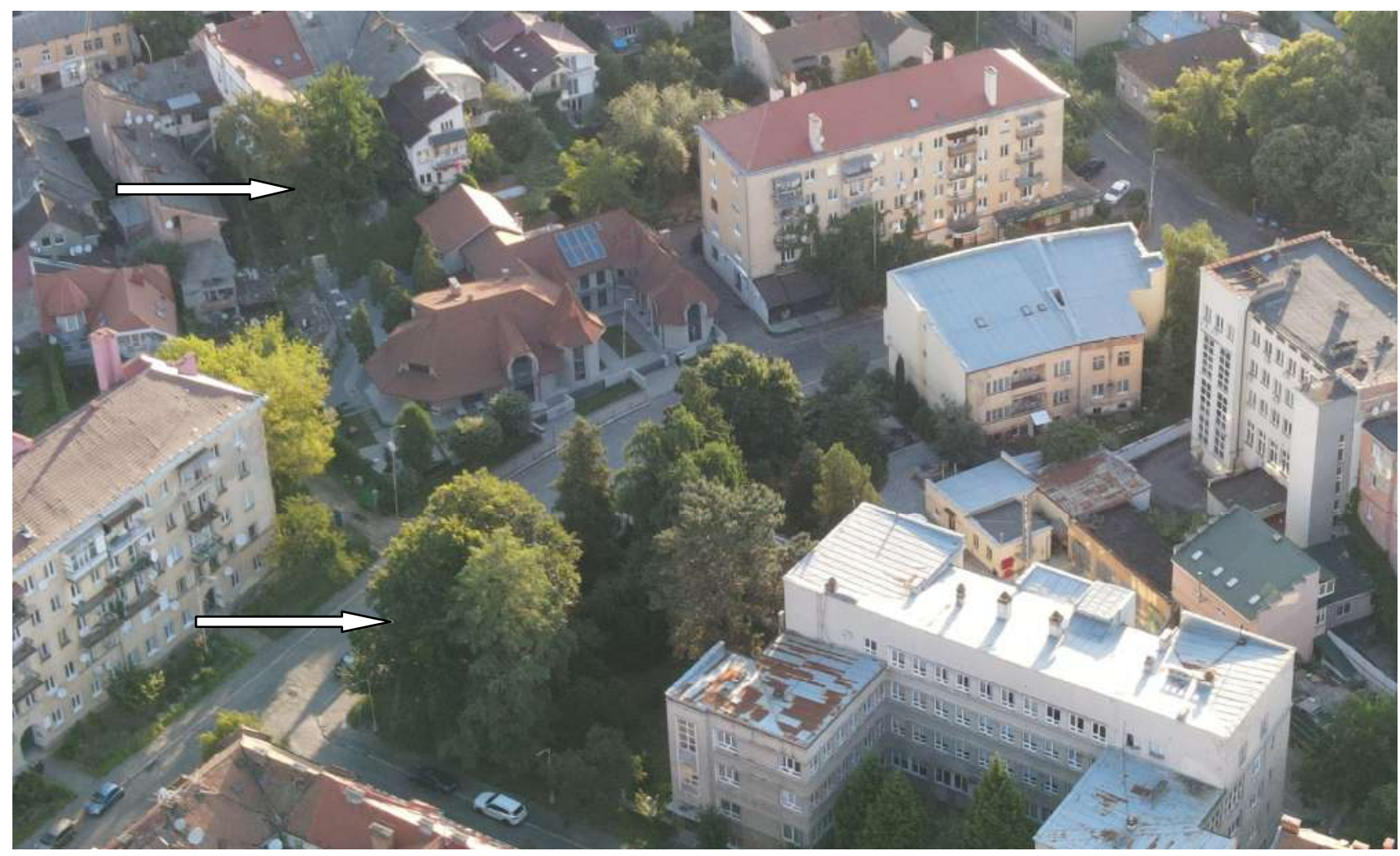

Рис. 5. Сучасний вигляд Дендросаду Лаудона біля дитячої лікарні (нижня стрілка) та його залишки позаду будинку Лаудона (верхня стрілка) (фото В. Трофименко)

Fig. 5. Modern view of the Laudon's Arboretum near the children's hospital (lower arrow) and its remains behind Laudon's house (upper arrow) (photo by V. Trofymenko)

У 1956 році в дендросаду був висаджений екземпляр криптомерії японської, що була передана від ботанічного саду УжДУ (цей вид був акліматизований при ділянках чайних плантацій на Червоній горі (Fodor 1957) та серед інших субтропічних рослин у 50 -х роках XX ст. у ботанічному саду (Bubriak 1957).

На прилеглих до парку ділянках дворових територій ростуть такі деревні види: два дерева туї західної (Thuja occidentalis) заввишки 10 м, широкогілочник східний - 9,4 м, клен гостролистий (Acer platanoides) - 16 м, туя складчаста -5 м. Також в останні роки були підсаджені молоді дерева сосни звичайної (шість штук заввишки від 5,1 до 7,6 м), ялини європейської, туї складчастої та магнолії Кобус (Magnolia kobus) (висота 2,3 м).

Як підсумок історії цього унікального саду відзначимо не вельми втішну статистику. За реєстром 1947 року, на збережених у районі вулиць Собранецької, Ференца Ракоці, Олександра Довженка клаптиках саду росло близько 100 видів дерев та кущів. За даними 1985 року - 42 види, нині ж їх близько 10 (Komendar 1990; 2005). 


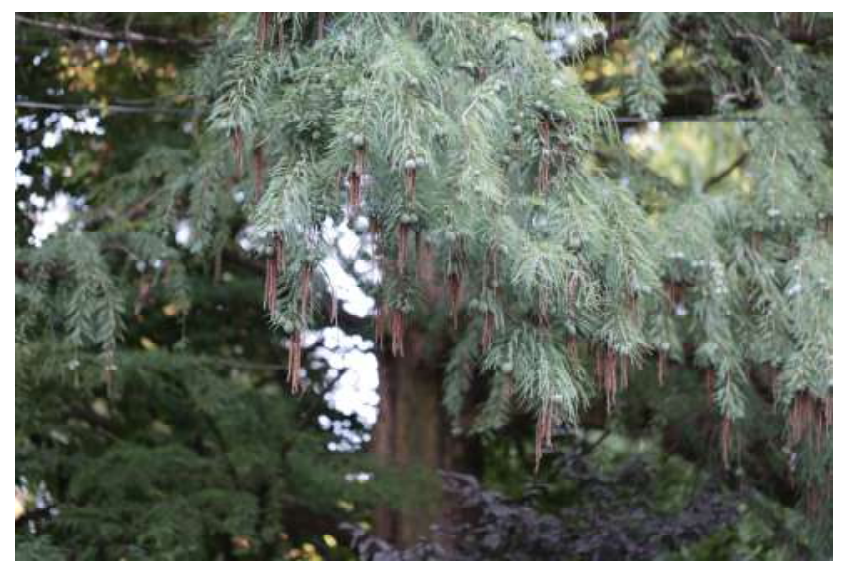

Рис. 6. Таксодій дворядний або болотний кипарис (Taxodium distichum) (фото Я. Гасинець)

Fig. 6. Bald cypress (Taxodium distichum) (photo by Ya. Hasynets)

\section{Сквер ім. Героїв Майдану.}

На початку 20-х років минулого століття відразу за площею Поштовою було закладено сквер (Рис. 8) на розі сучасних вулиць Ференца Ракоці, Олександра Довженка та Івана Крилова (тоді вул. Млинська). У 2014 році його було

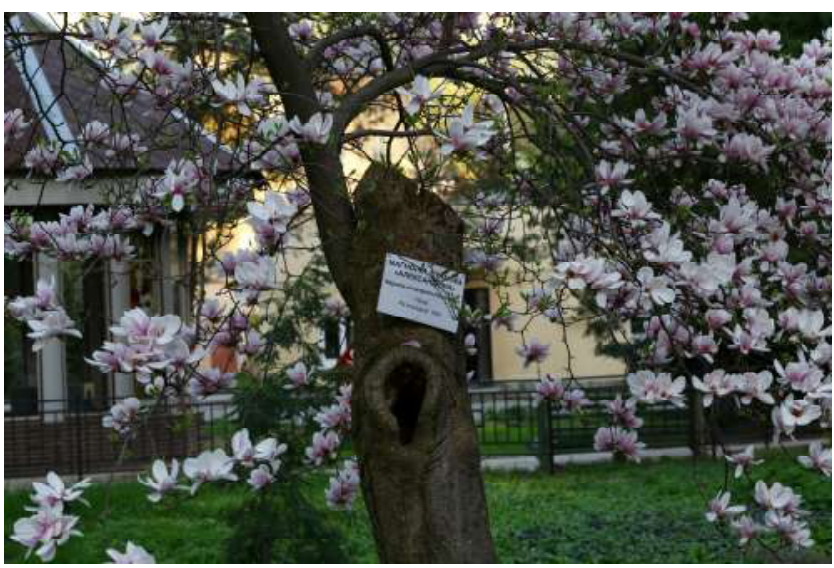

Рис. 7. Магнолія Суланжа (Magnolia soulangeana f. amabilis) з однією гілкою, що вціліла і пишно квітне (фото Я. Гасинець)

Fig. 7. Saucer magnolia (Magnolia soulangeana $\mathrm{f}$. amabilis) with one branch that survived and blooms profusely (photo by Ya. Hasynets)

перейменовано у «Сквер ім. Героїв Майдану» (Рис. 9, 10). Загальна площа скверу становить 0,55 га.

Станом на травень 2020 року в сквері ім. Героїв Майдану росте 61 екземпляр дерев та чагарників, що належать до 20 видів (Табл. 1).

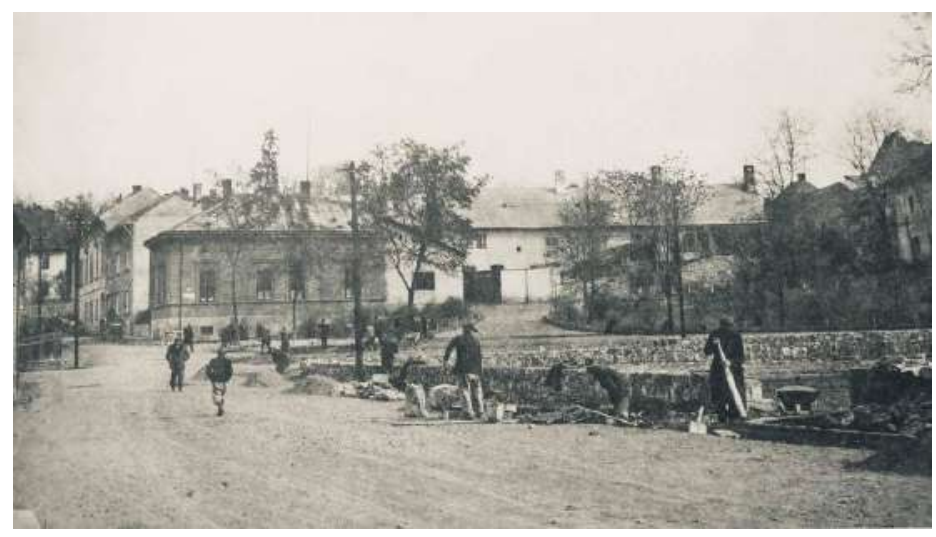

Рис. 8. Закладка скверу на вул. Млинській (сучасний сквер ім. Героїв Майдану). 1920-ті роки (Кобаль 2003)

Fig. 8. Foundation of the park square on the Mlynska street (modern park square named after the Heroes of the Maidan). 1920s (Kobal 2003)

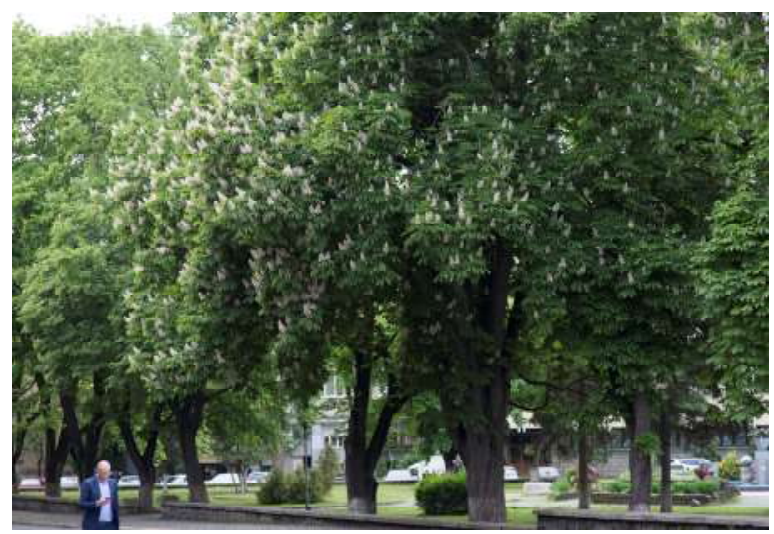

Рис. 9. Сучасний вигляд скверу ім. Героїв Майдану з вул. Олександра Довженка (фото Я. Гасинець)

Fig. 9. Modern view of the park square named after the Heroes of the Maidan form Oleksandra Dovzhenka street (photo by Ya. Hasynets) 


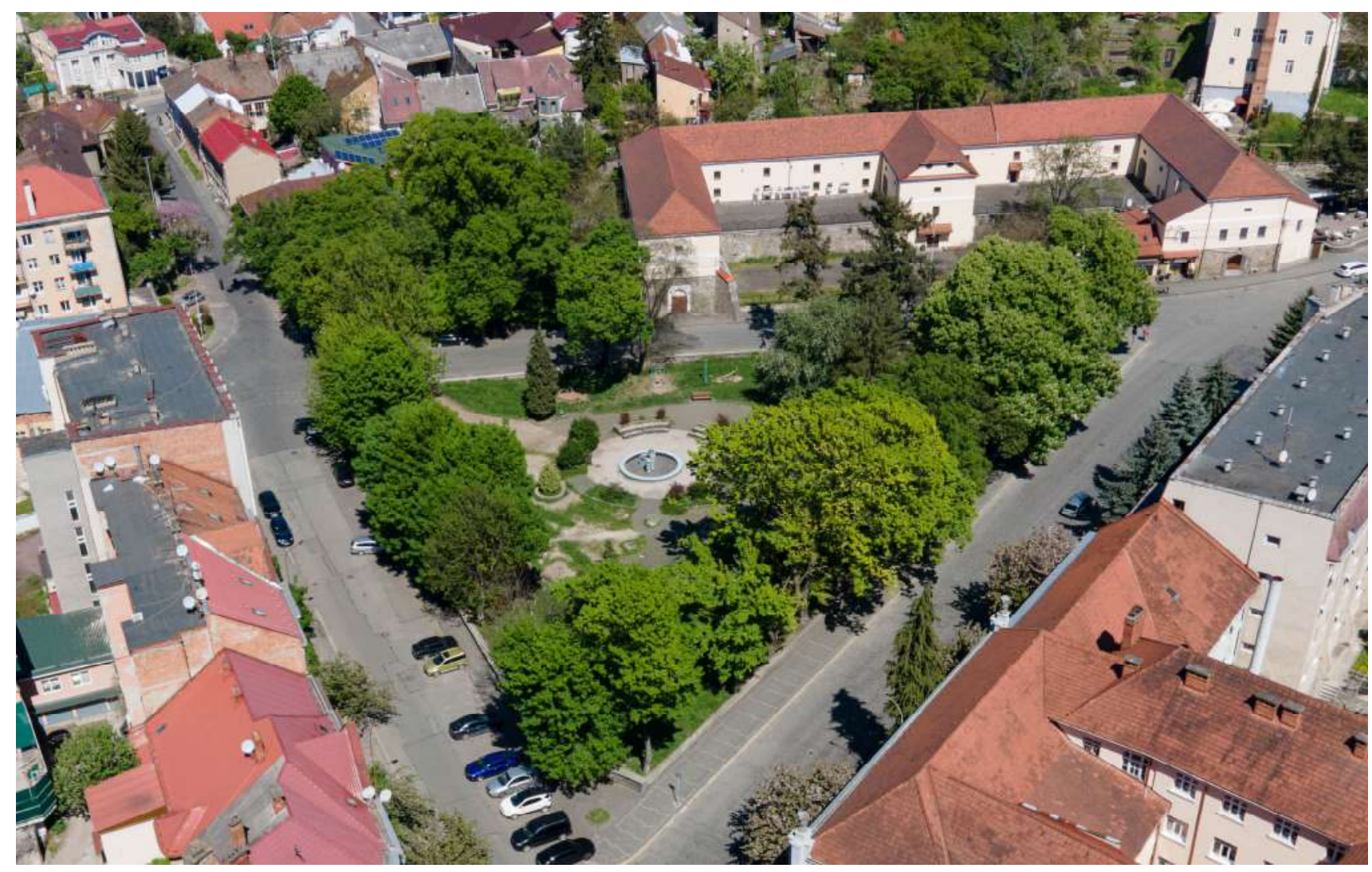

Рис. 10. Сучасний вигляд скверу ім. Героїв Майдану (фото В. Трофименко)

Fig. 10. Modern view of the park square named after the Heroes of the Maidan (photo by V. Trofymenko)

Таблиця 1. Видовий та кількісний склад дендрофлори скверу ім. Героїв Майдану

Table 1. Species and quantitative composition of the dendroflora of the square named after Heroes of the Maidan

\begin{tabular}{|c|c|c|c|}
\hline $\begin{array}{l}\text { № } \\
\text { п1/ா }\end{array}$ & Таксон & Походження & $\begin{array}{l}\text { Загальна } \\
\text { к-сть, шт. }\end{array}$ \\
\hline 1 & 2 & 3 & 4 \\
\hline \multicolumn{4}{|c|}{ PINOPHYTA } \\
\hline \multicolumn{4}{|c|}{ Cupressaceae } \\
\hline 1 & $\begin{array}{l}\text { Chamaecyparis lawsoniana (A. Murray) Parl. } \\
\text { Кипарисовник Лавсона }\end{array}$ & Інтродуцент & 1 \\
\hline 2 & $\begin{array}{l}\text { Thuja occidentalis L. } \\
\text { Туя західна }\end{array}$ & Інтродуцент & 3 \\
\hline \multicolumn{4}{|c|}{ Pinaceae } \\
\hline 3 & $\begin{array}{l}\text { Picea abies (L.) H. Karst. } \\
\text { Ялина європейська }\end{array}$ & Аборигенний вид & 1 \\
\hline 4 & $\begin{array}{l}\text { Pseudotsuga menziesii (Mirbel) Franco } \\
\text { Псевдотсуга Мензіса, дугласія тисолиста }\end{array}$ & Інтродуцент & 2 \\
\hline \multicolumn{4}{|c|}{ MAGNOLIOPHYTA } \\
\hline \multicolumn{4}{|c|}{ Aceraceae } \\
\hline 5 & $\begin{array}{l}\text { Acer campestre L. } \\
\text { Клен польовий }\end{array}$ & Аборигенний вид & 1 \\
\hline 6 & $\begin{array}{l}\text { Acer platanoides L. } \\
\text { Клен гостролистий }\end{array}$ & Аборигенний вид & 12 \\
\hline
\end{tabular}




\begin{tabular}{|c|c|c|c|}
\hline 1 & 2 & 3 & 4 \\
\hline 7 & $\begin{array}{l}\text { Acer pseudoplatanus L. } \\
\text { Клен-явір }\end{array}$ & Аборигенний вид & 1 \\
\hline 8 & $\begin{array}{l}\text { Acer saccharinum L. } \\
\text { Клен цукристий, к. сріблястий }\end{array}$ & Інтродуцент & 1 \\
\hline \multicolumn{4}{|c|}{ Berberidaceae } \\
\hline 9 & $\begin{array}{l}\text { Berberis thunbergii DC. } \\
\text { Барбарис Тунберга }\end{array}$ & Інтродуцент & 8 \\
\hline \multicolumn{4}{|c|}{ Caprifoliaceae } \\
\hline 10 & $\begin{array}{l}\text { Symphoricarpos albus Blake } \\
\text { Сніжноягідник білий }\end{array}$ & Інтродуцент & 4 \\
\hline 11 & $\begin{array}{l}\text { Weigela florida (Bunge) DC. } \\
\text { Вейгела квітуча }\end{array}$ & Інтродуцент & $\mathbf{1}$ \\
\hline \multicolumn{4}{|c|}{ Fabaceae } \\
\hline 12 & $\begin{array}{l}\text { Sophora japonica L. } \\
\text { Софора японська }\end{array}$ & Інтродуцент & 1 \\
\hline \multicolumn{4}{|c|}{ Fagaceae } \\
\hline 13 & $\begin{array}{l}\text { Castanea sativa Mill. } \\
\text { Каштан їстівний }\end{array}$ & Інтродуцент & 1 \\
\hline \multicolumn{4}{|c|}{ Hippocastanaceae } \\
\hline 14 & $\begin{array}{l}\text { Aesculus hippocastanum L. } \\
\text { Кінський каштан звичайний }\end{array}$ & Інтродуцент & 5 \\
\hline \multicolumn{4}{|c|}{ Malvaceae } \\
\hline 15 & $\begin{array}{l}\text { Hibiscus syriacus L. } \\
\text { Мальва сірійська деревовидна (Гібіск сірійський) }\end{array}$ & Інтродуцент & 1 \\
\hline \multicolumn{4}{|c|}{ Oleaceae } \\
\hline 16 & $\begin{array}{l}\text { Ligustrum vulgare L. } \\
\text { Бирючина звичайна }\end{array}$ & Аборигенний вид & 5 \\
\hline \multicolumn{4}{|c|}{ Rosaceae } \\
\hline 17 & $\begin{array}{l}\text { Cotoneaster horizontalis Decne } \\
\text { Кизильник горизонтальний }\end{array}$ & Інтродуцент & 2 \\
\hline 18 & $\begin{array}{l}\text { Padus avium Мill. } \\
\text { Черемха звичайна }\end{array}$ & Аборигенний вид & 1 \\
\hline \multicolumn{4}{|c|}{ Simaroubaceae } \\
\hline 19 & $\begin{array}{l}\text { Ailanthus altissima (Mill.) Swingle } \\
\text { Айлант найвищий }\end{array}$ & Інтродуцент & 1 \\
\hline \multicolumn{4}{|c|}{ Tiliaceae } \\
\hline 20 & $\begin{array}{l}\text { Tilia cordata Mill. } \\
\text { Липа серцелиста }\end{array}$ & Аборигенний вид & 9 \\
\hline \multicolumn{3}{|c|}{ Всього } & 61 \\
\hline
\end{tabular}

Відділ голонасінні (Pinophyta) представлений двома родинами $\mathrm{i}$ чотирма видами. Відділ квіткові (Magnoliophyta) включає 11 родин і 57 видів. Найбільшою кількістю видів представлена родина Aceraceae - чотири види. Чотири родини (Cupressaceae, Pinaceae, Caprifoliaceae, Rosaceae) включають по два види, інші родини - по одному виду.

Найбільш чисельними у сквері $є$ посадки клену гостролистого - 12 особин, липи серце- листої - дев'ять особин та гіркокаштану звичайного - п'ять особин (Рис. 9-10). Серед чагарників найбільш широко представлені бирючина звичайна, барбарис Тунберга, сніжноягодник білий.

Серед голонасінних виділяються два дерева псевдотсуги Мензіса, або дугласії (Рис. 11). Прикрасою скверу є вейгела квітуча та черемха звичайна. 


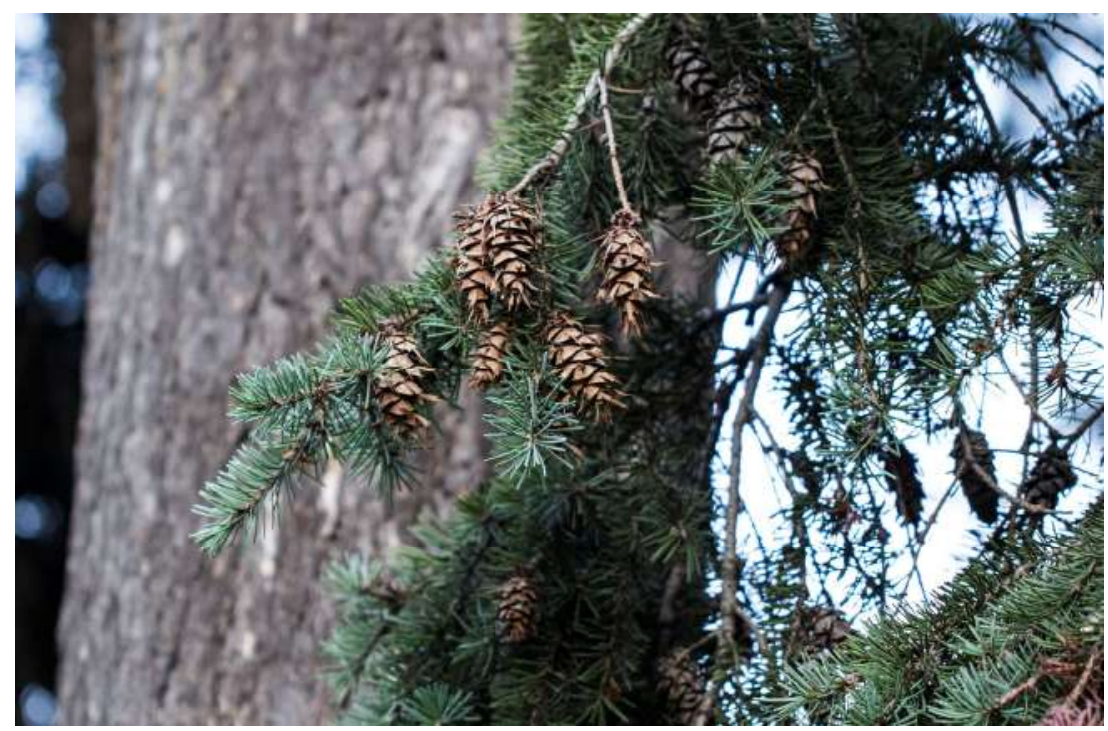

Рис. 11. Псевдотсуга Мензіса або дугласія (Pseudotsuga menziesii) (фото Я. Гасинець)

Fig. 11. Douglas-fir (Pseudotsuga menziesii) (photo by Ya. Hasynets)

\section{Партер на площі Народній.}

На площі Народній перед будівлею Закарпатської ОДА знаходиться партер, який у сучасних межах закладено в 1936-1938 роках (Рис. 12). Згідно із первісними планами забудови мікрорайону, замість великого центрального газону мала бути проїжджа частина, адже спочатку архітектори хотіли, щоб великий міст з'єднував береги Ужа якраз навпроти будівлі земського уряду. Коли проєкт змінили, потреба в такій широкій проїжджій частині відпала - так і з'явилася прямокутна зелена зона посеред площі (Olashyn 2013).

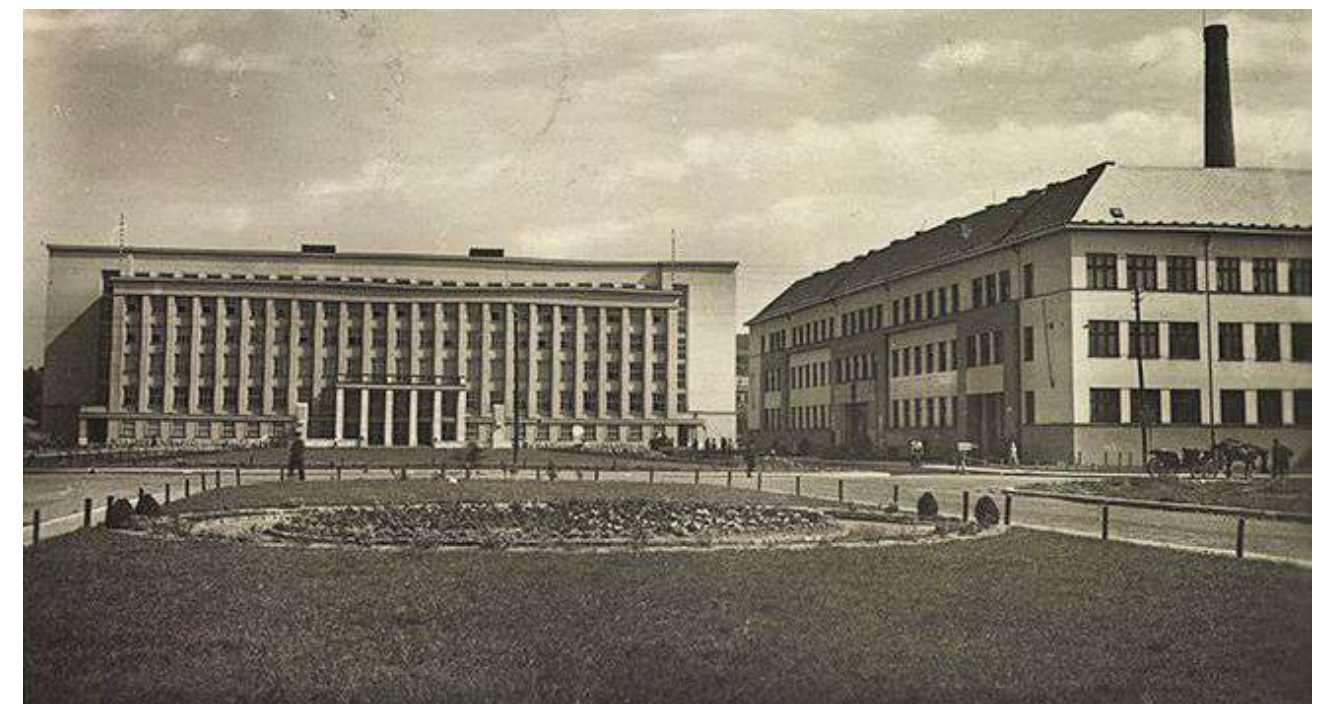

Рис. 12. Партер на пл. Народній у 1938 р. (поштова листівка)

Fig. 12. Parterre on the Narodna square in 1938 (postcard)

Партер є пам'яткою садово-паркового мистецтва місцевого значення. Домінуючими архітектурними стилями будівель на Народній площі $\epsilon$ неокласицизм та функціоналізм (Olashyn 2013). Рішення чехословацького партеру на Народній площі спирається на найкращі взірці газонних партерів класицизму, для якого характерні комбінація газону 3 акуратно підстриженими кущами, що висаджені в одну лінію. На ретросвітлинах видно, що іiі свідомо не засаджували великою кількістю рослин (Рис. 12, 13, 14). Лише по периметру 
росли молоді кущі, посередині ж це був класичний газон. Такий вигляд партеру 3 кулевидними кущами самшиту (Buxus

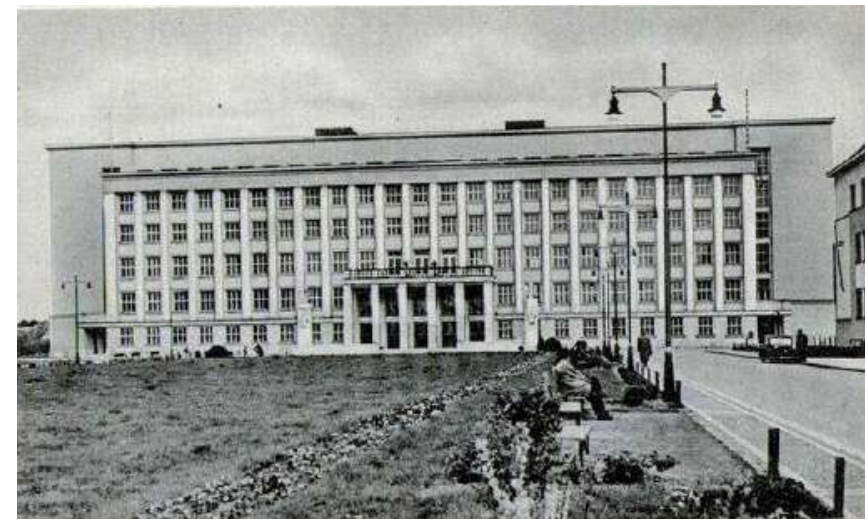

Рис. 13. Площа Народна, 1938 рік

(https://www.facebook.com/transcarpathian.heritage)

Fig. 13. Narodna square, 1938

(https://www.facebook.com/transcarpathian.heritage)

Згідно із С.С. Фодор (Fodor 1956) у середині 50 -х років XX ст. по краям партеру симетрично було висаджено кущі самшиту, а також бирючини, барбарису Тунберга, ірги канадської (Amelanchier canadensis (L.) Medik.), кущові троянди столисті (Rosa centifolia L.), що культивуються ще 3 середніх віків та мають дуже запашні квіти. Більша частина центрального газону цього скверу була огороджена щільним живоплотом таволги японської. На суцільному зеленому фоні газону контрастно виділялись троянди та велика квіткова клумба в центрі (Рис. 15).

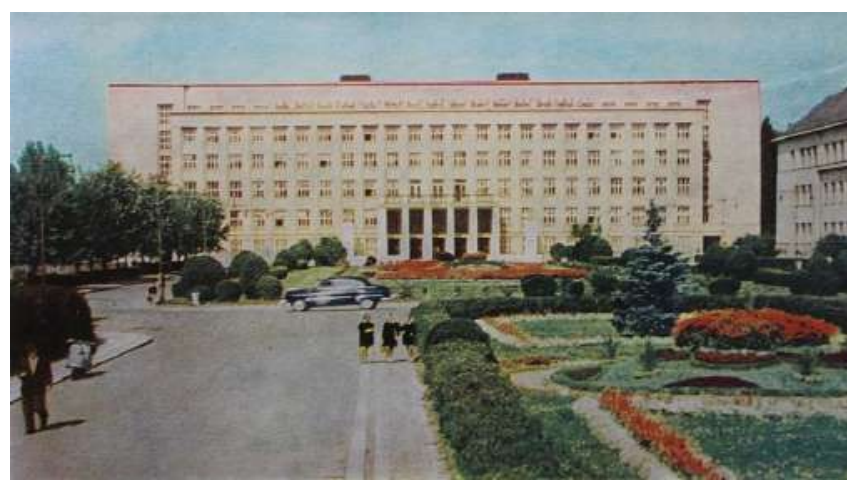

Рис. 15. Площа Народна в Ужгороді, 1962 рік (https://www.facebook.com/transcarpathian.heritage)

Fig. 15. Narodna square in Uzhhorod, 1962

(https://www.facebook.com/transcarpathian.heritage)

За свою 80-річну історію існування партер на площі Народній виглядав по-різному sempervirens) колись пропонував Ф. Крупка на одному зі своїх ескізних проектів.

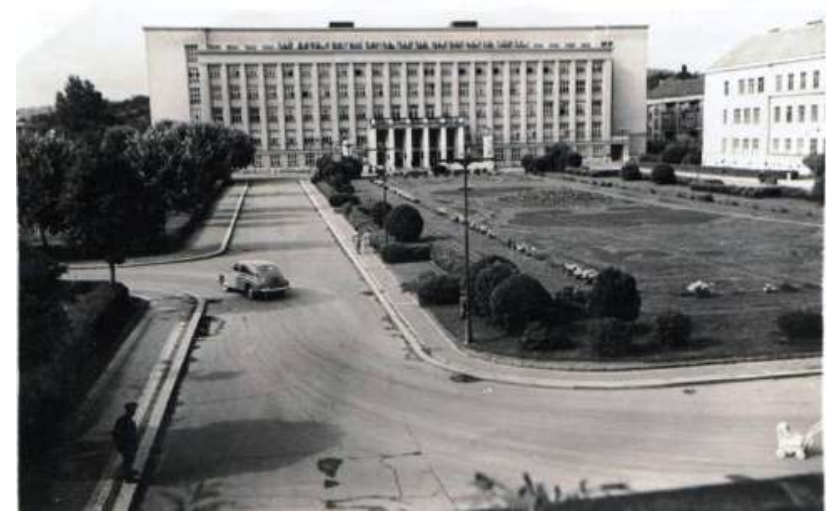

Рис. 14. Площа Народна, 1960-ті роки (https://www.facebook.com/transcarpathian.heritage)

Fig. 14. Narodna square, beginning of 1960s' (https://www.facebook.com/transcarpathian.heritage)

\section{Путівник Ужгородом, виданий} видавництвом «Карпати» 1990 року, розповідає, що теперішня площа Народна в будь-яку пору року мала неповторне зелене оздоблення (Kushnir, Ugliay 1990). На центральній клумбі росли самшит, бирючина, барбарис, біота східна, спірея та садовий жасмин звичайний (Philadelphus coronarius L.). Кущі бирючини регулярно підстригали, тому вони малу кулясту форму. Дуже прикрашали площу «фонтанчики» вічнозеленої юкки нитчастої (Yucca filamentosa L.), яка теж прижилася в Ужгороді 3 «легкої руки» чеських ботаніків (Рис. 16).

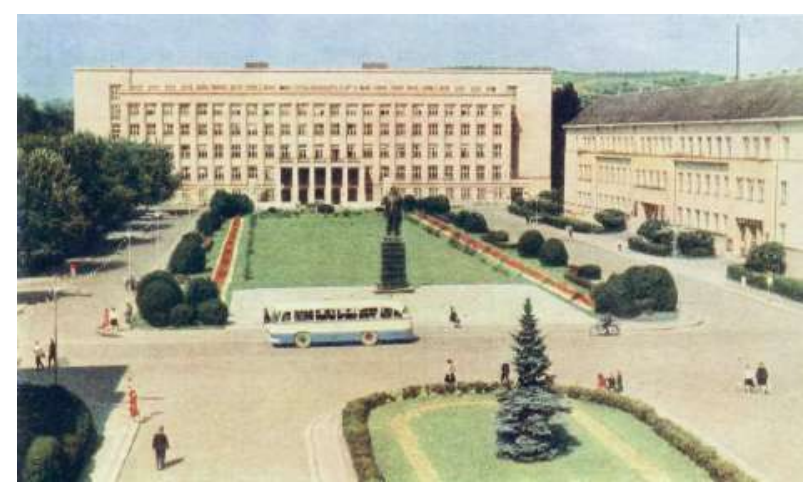

Рис. 16. Площа Народна в Ужгороді, 1967 рік (https://www.facebook.com/transcarpathian.heritage)

Fig. 16. Narodna square in Uzhhorod, 1967 (https://www.facebook.com/transcarpathian.heritage)

(Рис. 12-18). Сучасний проект реконструкції партеру з фрагментуванням колись суцільного 
газонного покриття, як це було задумано згідно із первісним проєктом площі (Рис. 17), отримав значну критику та спротив серед громади міста. Зараз на партері по периметру висаджені кущі самшиту, в центрі був закладений у 2014 році розарій, а в 2015 році відкрили фонтан. У березні 2018 року серед троянд висаджена ялина колюча (Picea pungens), яка згодом буде виконувати функцію живого новорічного дерева (Рис. 18).

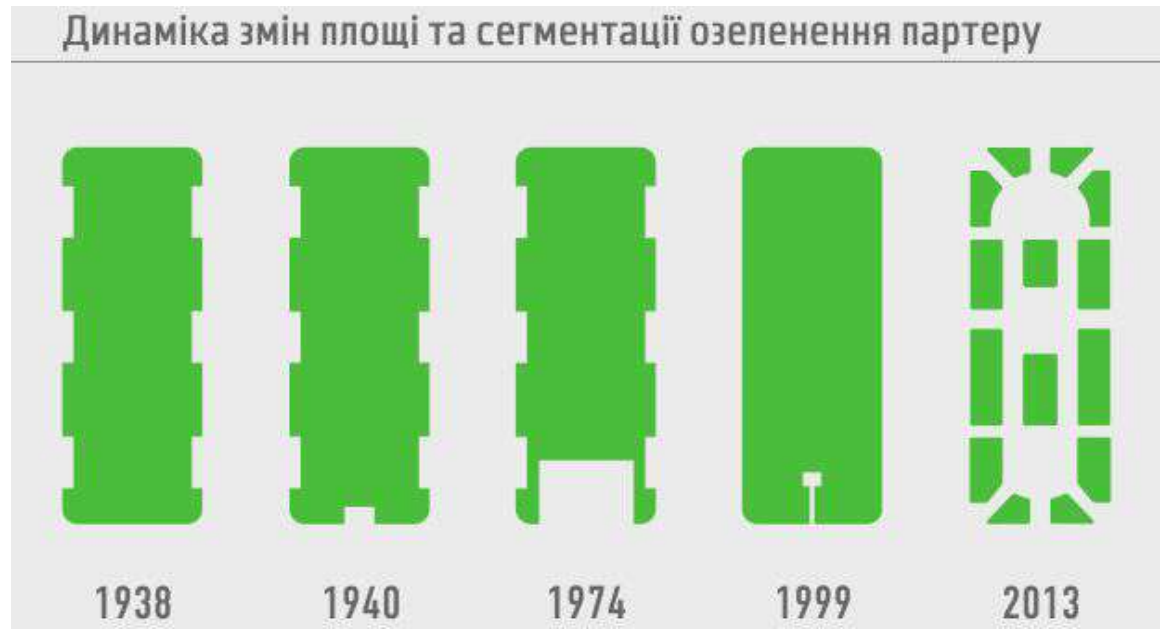

Рис. 17. Динаміка змін та сегментації озеленення партеру на площі Народній (Олашин, 2013)

Fig. 17. Dynamics of changes and segmentation of Parterre landscaping on the Narodna Square (Olashyn, 2013)

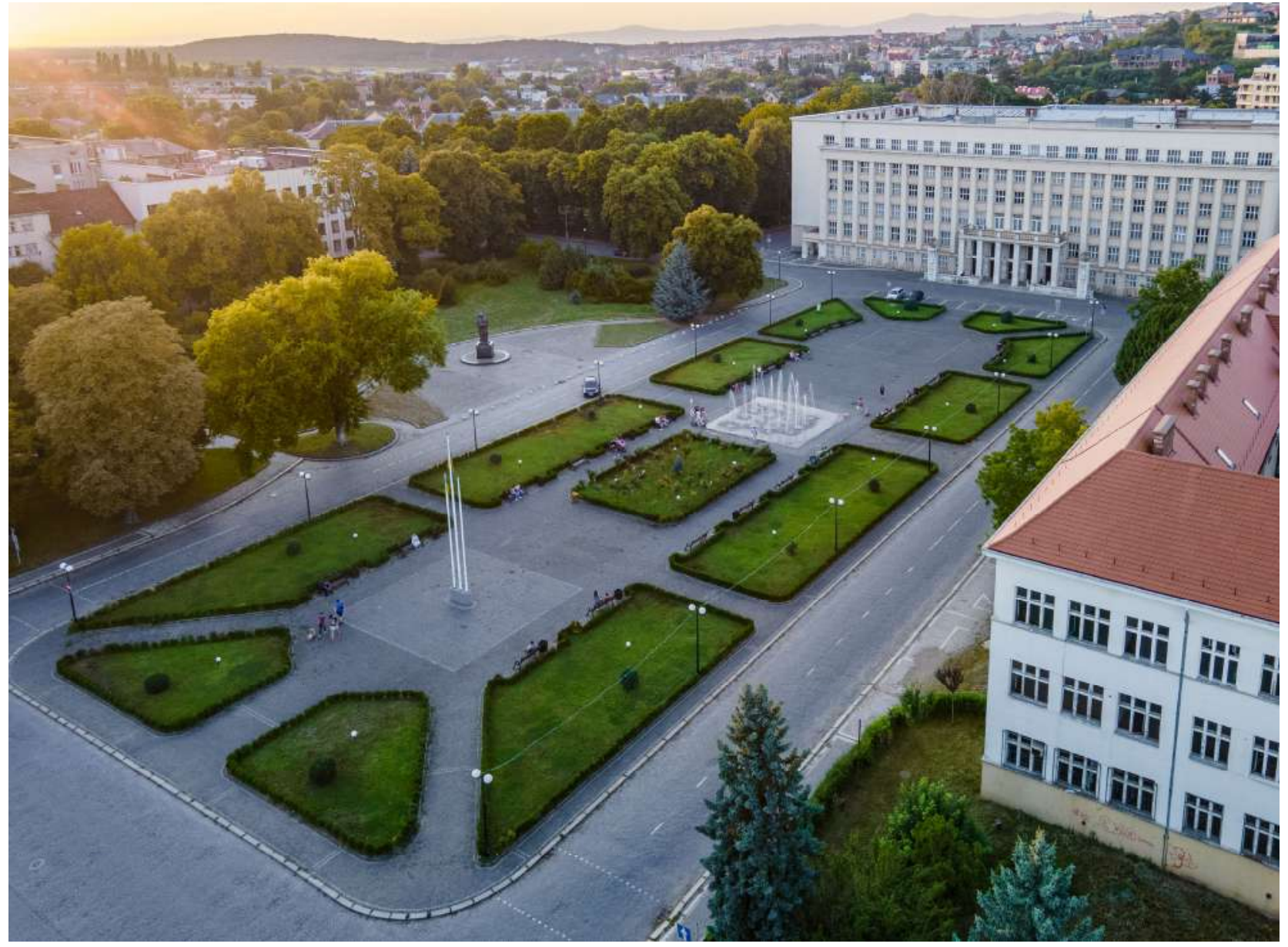

Рис. 18. Сучасний вигляд площі Народної (фото В. Трофименко)

Fig. 18. Modern view of the Narodna Square (photo by V. Trofymenko) 

троянд).

Сквер на площі Народній (колищній сад

Розбудову площі почали на початку 1930$\mathrm{x}$ років. Попервах було зведено будівлю земського уряду Підкарпатської Русі, а паралельно - земський суд. 3 іншого боку площі згідно із проєктом повинна була постати будівля театру, однак з якихось причин замість того, аби завершити ансамбль площі, будівельники ударними темпами зводили інші будівлі Малого Галагова - як адміністративні, так і житлові. Глибокий котлован, викопаний для фундаменту театру, простояв до 1938 року, коли реалізації плану завадив початок другої Світової війни - територія Закарпаття за Віденським арбітражем відійшла до Угорщини. I вже тільки у 1954 році пристойного вигляду вирішили надати й котловану, що так i залишився посеред площі незабудованим до сьогодні. Зараз перепад рельєфу становить 1,21,5 м по відношенню до рівня площі Народної (Комплексная зеленая зона г. Ужгорода, 1982). Згідно 3 C.C. Фодор (Fodor 1956) для тимчасового озеленення тут були використані троянди, самшити та багато деревних порід. У розарії ж росли близько 30 сортів троянд, котрі цвіли $з$ травня по листопад (Fedaka 2010; Literati 2015). В асортименті були використані чотири групи троянд - ремонтантні, чайно-гібридні, виткі та штамбові. Останні домінували в розарії, на їх частку припадало $75 \%$ всіх троянд (Kompleksnaja ... 1982), які росли аж до 80-х років ХХ ст., коли з часом через вік кущів почали випадати 3 посадок.

Пізніше були висаджені ліріодендрон тюльпановий, сосна гірська (Pinus mugo), церцис європейський, таволга японська, декілька видів кизильника, кипарисовики, ялівці. Декілька років тому на території скверу було висаджені три молоді дерева магнолії.

Станом на листопад 2020 року в сквері нараховувалося 24 види рослин у загальній кількості 133 особини (Табл. 2, Рис. 19). 3 них голонасінні представлені двома родинами i п'ятьма видами. Квіткові включають 10 родин і 19 видів. Найбільш широко представлені родини Rosaceae (6 видів), Cupressaceae та Magnoliaceae (по 4 види). Переважають інтродуковані рослини - 18 видів, відповідно місцеві представлені п'ятьма видами. Серед інтродукованих рослин найбільше видів китайсько-японського (7 видів) та північноамериканського (4 види) походження. Найчисельнішими серед дерев $\epsilon$ липа серцелиста та сосна гірська - по дев'ять особин. Дерева липи були висаджені ще у чехословацький період (уздовж вулиці Дмитра Менделєєва), а сосни - у радянський період. Чагарники представлені 12 видами. Кількісно серед них переважають такі види, як таволга японська - 26 особин, кизильник блискучий (Cotoneaster lucidus) - 22 особини, таволга Вангута (Spirea $\times$ vanhouttei) - 14 особин та садовий жасмин звичайний - дев'ять особин.

Таблиця 2. Видовий та кількісний склад дендрофлори скверу на площі Народній

Table 2. Species and quantitative composition of the dendroflora of the park square on the Narodna Square

\begin{tabular}{|c|c|c|c|}
\hline $\begin{array}{l}\text { № } \\
\text { п1/I }\end{array}$ & Таксон & Походження & $\begin{array}{c}\text { Загальна } \\
\text { кількість, } \\
\text { екз. }\end{array}$ \\
\hline 1 & 2 & 3 & 4 \\
\hline \multicolumn{4}{|c|}{ PINOPHYTA } \\
\hline \multicolumn{4}{|c|}{ Cupressaceae } \\
\hline 1 & $\begin{array}{l}\text { Chamaecyparis sp. } \\
\text { Кипарисовик }\end{array}$ & Інтродуцент & 3 \\
\hline 2 & $\begin{array}{l}\text { Thuja plicata } \text { D. Don. } \\
\text { Туя складчаста, т. велетенська }\end{array}$ & Інтродуцент & 2 \\
\hline \multicolumn{4}{|c|}{ Pinaceae } \\
\hline 3 & $\begin{array}{l}\text { Picea pungens Engelm. } \\
\text { Ялина колюча }\end{array}$ & Інтродуцент & 1 \\
\hline 4 & $\begin{array}{l}\text { Pinus mugo Turra (P. mughus Scop.) } \\
\text { Сосна гірська, с. жереп }\end{array}$ & Аборигенний вид & 9 \\
\hline \multicolumn{4}{|c|}{ Taxaceae } \\
\hline 5 & $\begin{array}{l}\text { Taxus baccata L. } \\
\text { Тис ягідний, негній-дерево }\end{array}$ & Аборигенний вид & 1 \\
\hline
\end{tabular}




\begin{tabular}{|c|c|c|c|}
\hline $\mathbf{1}$ & 2 & 3 & 4 \\
\hline \multicolumn{4}{|c|}{ MAGNOLIOPHYTA } \\
\hline \multicolumn{4}{|c|}{ Aquifoliaceae } \\
\hline 6 & $\begin{array}{l}\text { Ilex aquifolium } \mathrm{L} \text {. } \\
\text { Падуб гостролистий }\end{array}$ & Інтродуцент & 3 \\
\hline \multicolumn{4}{|c|}{ Caprifoliaceae } \\
\hline 7 & $\begin{array}{l}\text { Viburnum rhytidophyllum Hemsl. } \\
\text { Калина зморщенолиста }\end{array}$ & Інтродуцент & 2 \\
\hline \multicolumn{4}{|c|}{ Celastraceae } \\
\hline 8 & $\begin{array}{l}\text { Euonymus japonicus Thunb. } \\
\text { Бруслина японська }\end{array}$ & Інтродуцент & 4 \\
\hline \multicolumn{4}{|c|}{ Fabaceae } \\
\hline 9 & $\begin{array}{l}\text { Cercis siliquastrum L. } \\
\text { Церцис європейський, ц. стручковий }\end{array}$ & Інтродуцент & 1 \\
\hline \multicolumn{4}{|c|}{ Magnoliaceae } \\
\hline 10 & $\begin{array}{l}\text { Magnolia kobus DC. } \\
\text { Магнолія Кобус }\end{array}$ & Інтродуцент & 1 \\
\hline 11 & $\begin{array}{l}\text { Magnolia } \times \text { soulangeana } \text { Soulange-Bodin. } \\
\text { Магнолія Суланжа }\end{array}$ & Інтродуцент & 2 \\
\hline 12 & $\begin{array}{l}\text { Magnolia sp. } \\
\text { Магнолія }\end{array}$ & Інтродуцент & 3 \\
\hline 13 & $\begin{array}{l}\text { Liriodendron tulipifera } \mathrm{L} \text {. } \\
\text { Лiрiодендрон тюльпановий, тюльпанове дерево }\end{array}$ & Інтродуцент & 2 \\
\hline \multicolumn{4}{|c|}{ Moraceae } \\
\hline 14 & $\begin{array}{l}\text { Morus nigra } \mathrm{L} \text {. } \\
\text { Шовковиця чорна, форма плакуча }\end{array}$ & Інтродуцент & 1 \\
\hline \multicolumn{4}{|c|}{ Oleaceae } \\
\hline 15 & $\begin{array}{l}\text { Ligustrum vulgare L. } \\
\text { Бирючина звичайна }\end{array}$ & Аборигенний вид & 3 \\
\hline 16 & $\begin{array}{l}\text { Syringa vulgaris L. } \\
\text { Бузок звичайний }\end{array}$ & Інтродуцент & 2 \\
\hline \multicolumn{4}{|c|}{ Philadelphaceae } \\
\hline 17 & $\begin{array}{l}\text { Philadelphus coronarius L. } \\
\text { Садовий жасмин звичайний }\end{array}$ & Інтродуцент & 9 \\
\hline \multicolumn{4}{|c|}{ Rosaceae } \\
\hline 18 & $\begin{array}{l}\text { Cotoneaster horizontalis Decne } \\
\text { Кизильник горизонтальний }\end{array}$ & Інтродуцент & 5 \\
\hline 19 & $\begin{array}{l}\text { Cotoneaster lucidus Schlecht. } \\
\text { Кизильник блискучий }\end{array}$ & Інтродуцент & 22 \\
\hline 20 & $\begin{array}{l}\text { Laurocerasus officinalis M.J. Roemer. } \\
\text { Лавровишня лікарська }\end{array}$ & Інтродуцент & 3 \\
\hline 21 & $\begin{array}{l}\text { Pyracantha coccinea M.J. Roemer. } \\
\text { Піраканта яскраво-червона }\end{array}$ & Інтродуцент & 5 \\
\hline 22 & $\begin{array}{l}\text { Spiraea jароnica L. fil. } \\
\text { Таволга японська }\end{array}$ & Інтродуцент & 26 \\
\hline 23 & $\begin{array}{l}\text { Spirea } \times \text { vanhouttei }(\text { Briot) Carrière } \\
\text { Таволга Вангута }\end{array}$ & Інтродуцент & 14 \\
\hline \multicolumn{4}{|c|}{ Tiliaceae } \\
\hline 24 & $\begin{array}{l}\text { Tilia cordata Mill. } \\
\text { Липа серцелиста }\end{array}$ & Аборигенний вид & 9 \\
\hline \multicolumn{3}{|c|}{ Всього } & 133 \\
\hline
\end{tabular}




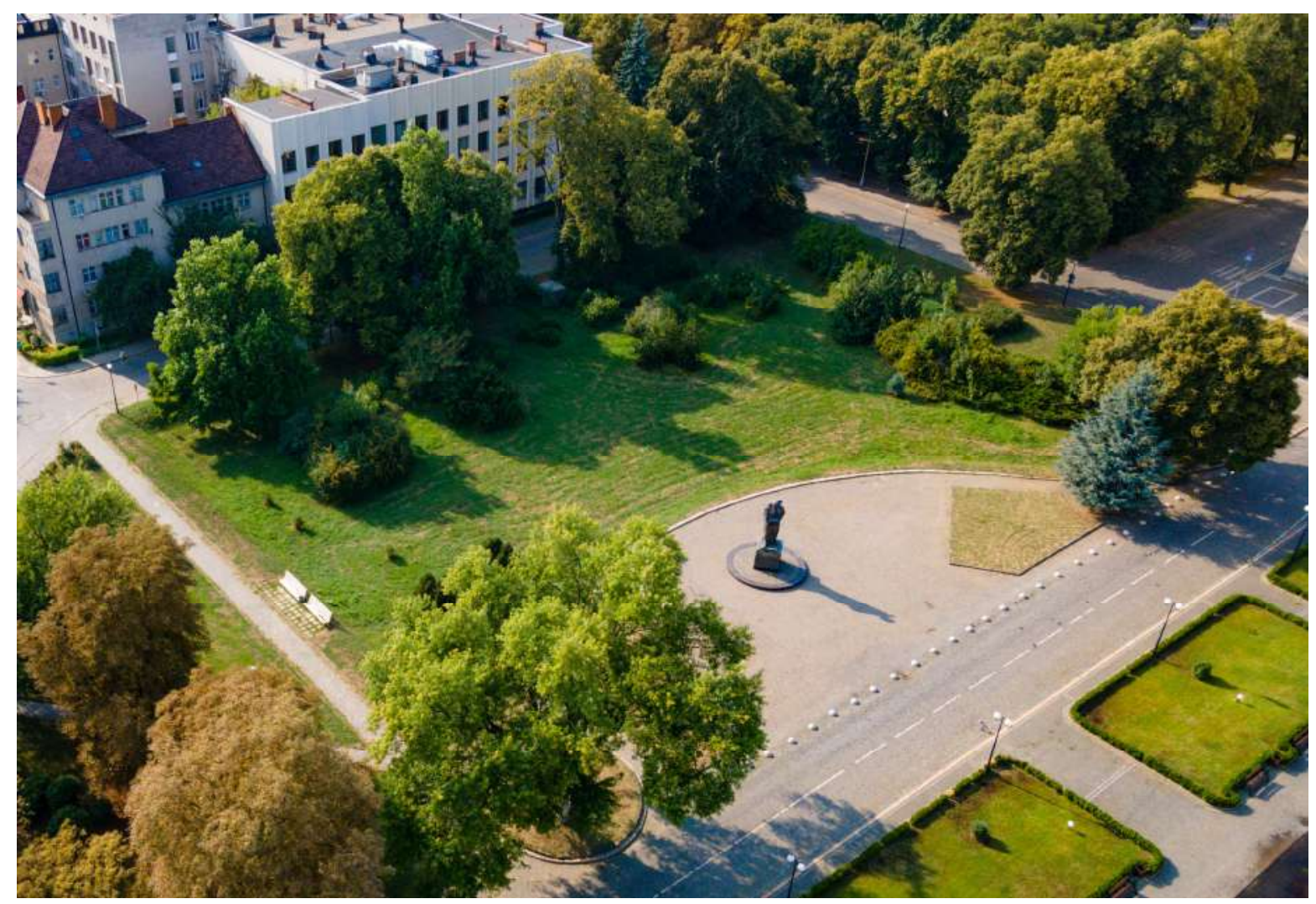

Рис. 19. Сучасний вигляд скверу на площі Народній (фото В. Трофименко)

Fig. 19. Modern view of park square on the Narodna Square (photo by V. Trofymenko)

\section{Сквер імені Томаша Масарика.}

Приблизно в ті ж роки, що і партер на пл. Народній, було закладено сквер імені Томаша Масарика, названого на честь першого Президента Чехословаччини (1918-1935) (Рис. 20). На теперішній час площа скверу становить 0,57 га. Із 2012 року сквер є об'єктом природно-заповідного фонду, паркомпам'яткою садово-паркового мистецтва місцевого значення.

С.C. Фодор (Fodor 1956) у дисертації відмічає, що сквер Томаша Масарика, в основному, складався 3 хвойних порід: ялини, псевдотсуги Мензіса, сосни, тисів, кипарисовиків і туй, у центрі височів великий екземпляр клена Шведлера (Acer platanoides Schwedleri) (один із найдавніших сортів клену гостролистого, відомий з 1869 року, що навесні має червоне забарвлення листків), а з двох боків - тополі пірамідальні (Populus italica (DuRoi) Moench).

На цей час у сквері росте 21 вид деревних рослин у кількості 119 особин (Табл. 3, Рис. 21, 22). Хвойні, які зосереджені з північного боку скверу біля транспортного мосту, представлені чотирма видами: псевдотсуга Мензіса - 10 особин, ялина європейська - сім особин, широкогілочник східний - чотири особини, сосна гірська - одна особина. По периметру 3 цього боку сквер оточений тополею чорною (ф. пірамідальна) в кількості сім екземплярів (Рис. 23). Це одні 3 найстаріших посадок у сквері. Також у північній частині скверу ростуть три дерева стифнолобіума японського (Styphnolobium japonicum (Sophora japonica)), декілька екземплярів катальп бігноєвидних (Catalpa bignonioides), ясени звичайний (Fraxinus excelcior) та пенсільванський (F. pennsylvanica).

По периметру, що прилягає до вул. Юрія Гойди, можна помітити бордюр 3 бирючини звичайної. 3 боку цієї ж вулиці росте молодий екземпляр брусонеції паперової, що у 40-х роках XX ст. була інтродукована у ботанічному саду УжДУ (Рис. 24). Більш старший екземпляр було вилучено у 2018 році. Молодий екземпляр виник як коренева поросль, що характерно для цього виду. 


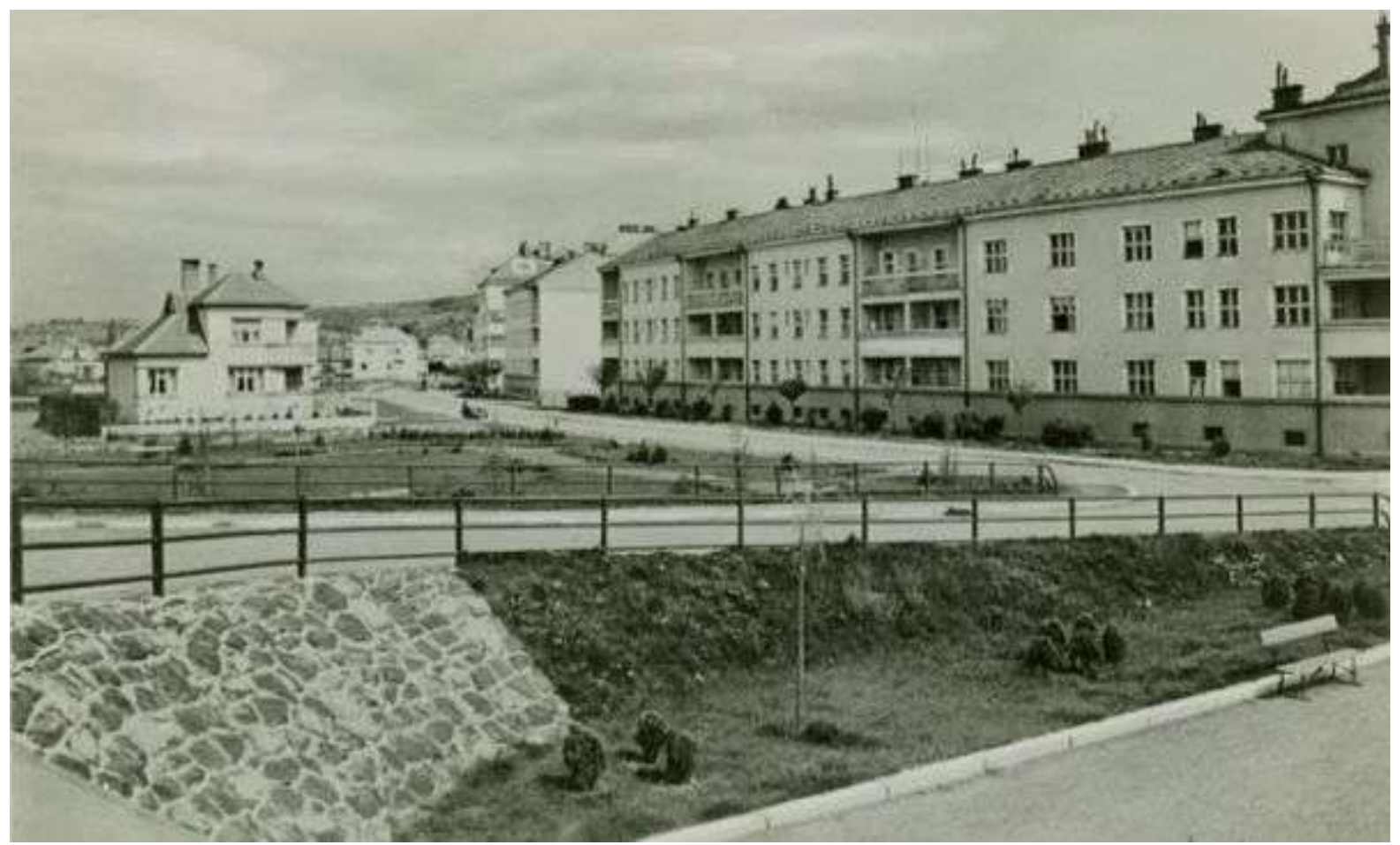

Рис. 20. Забудова Малого Галагова з боку нового транспортного мосту та закладання скверу (поштова листівка 1938 року)

Fig. 20. Building of the Malyi Galagov from the side of the new transport bridge and laying of the park square (postcard of 1938)

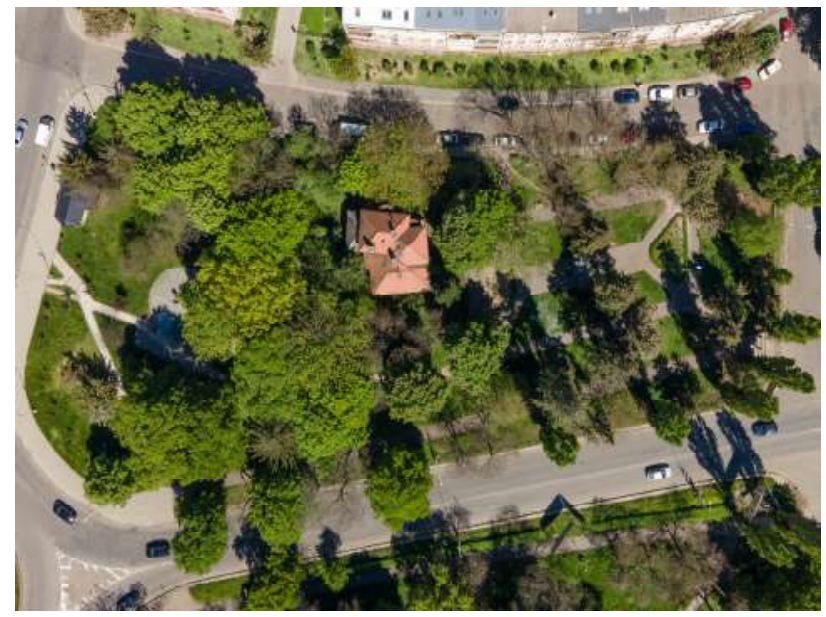

Рис. 21. Сучасний вигляд скверу імені Томаша Масарика (фото В. Трофименко)

Fig. 21. Modern view of the Tomas Masaryk park square (photo by V. Trofymenko)

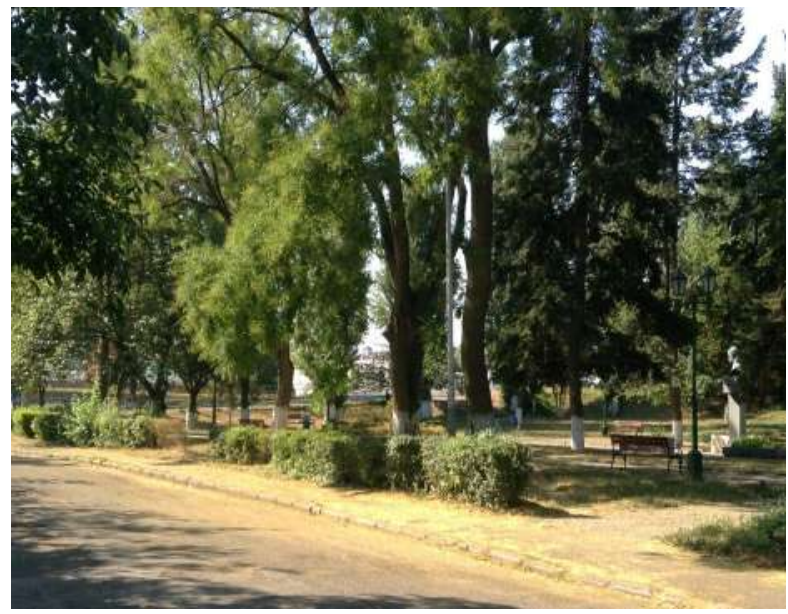

Рис. 22. Сквер ім. Томаша Масарика 3 боку вул. Юрія Гойди (https://ru.foursquare.com/v/сквер-масарика /4fddceeae4b01549c0ae3af0)

Fig. 22. The Tomas Masaryk park square form the Yuria Hoidy street (https://ru.foursquare.com/v/сквер-масарика /4fddceeae4b01549c0ae3af0) 


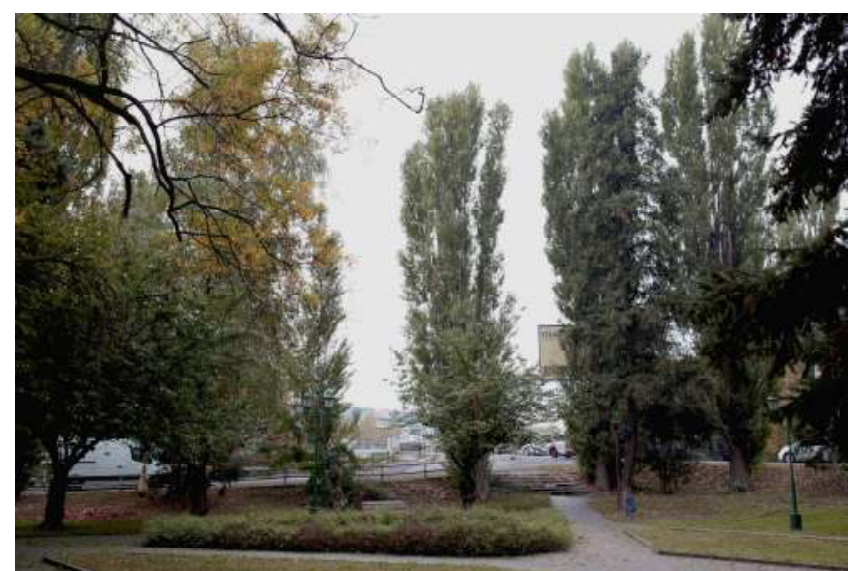

Рис. 23. Посадки тополі чорної (Populus nigra) ф. пірамідальна по периметру скверу ім. Томаша Масарика (фото Я. Гасинець)

Fig. 23. Plantings of black poplar (Populus nigra) f. pyramidal around the perimeter of the Tomas Masaryk park square (photo by Ya. Hasynets)

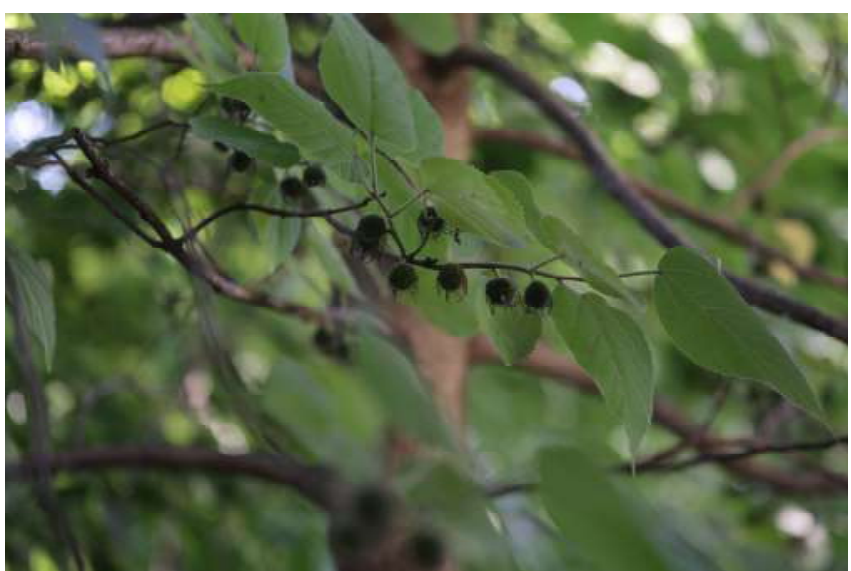

Рис. 24. Брусонеція паперова або паперове дерево (Broussonetia papyrifera) у сквері ім. Томаша Масарика (фото Я. Гасинець)

Fig. 24. The paper mulberry (Broussonetia papyrifera) in the Tomas Masaryk park square (photo by Ya. Hasynets)

Таблиця 3. Видовий та кількісний склад дендрофлори скверу імені Томаша Масарика

Table 3. Species and quantitative composition of the dendroflora of the Tomas Masaryk park square

\begin{tabular}{|c|c|c|c|}
\hline $\begin{array}{l}\text { № } \\
\text { II/II }\end{array}$ & Таксон & Походження & $\begin{array}{c}\text { Загальна } \\
\text { кількість, екз. }\end{array}$ \\
\hline 1 & 2 & 3 & 4 \\
\hline \multicolumn{4}{|c|}{ PINOPHYTA } \\
\hline \multicolumn{4}{|c|}{ Cupressaceae } \\
\hline 1 & $\begin{array}{l}\text { Platycladus orientalis (L.) Franco } \\
\text { Широкогілочник східний, біота східна }\end{array}$ & Інтродуцент & 4 \\
\hline \multicolumn{4}{|c|}{ Pinaceae } \\
\hline 2 & $\begin{array}{l}\text { Picea abies (L.) H. Karst. } \\
\text { Ялина європейська }\end{array}$ & Аборигенний вид & 7 \\
\hline 3 & $\begin{array}{l}\text { Pinus mugo Turra (P. mughus Scop.) } \\
\text { Сосна гірська, с. жереп }\end{array}$ & Аборигенний вид & 1 \\
\hline 4 & $\begin{array}{l}\text { Pseudotsuga menziesii (Mirbel) Franco } \\
\text { Псевдотсуга Мензіса, дугласія тисолиста }\end{array}$ & Інтродуцент & 10 \\
\hline \multicolumn{4}{|c|}{ MAGNOLIOPHYTA } \\
\hline \multicolumn{4}{|c|}{ Betulaceae } \\
\hline 5 & $\begin{array}{l}\text { Betula pendula Roth } \\
\text { Береза повисла, б. бородавчаста }\end{array}$ & Аборигенний вид & 1 \\
\hline \multicolumn{4}{|c|}{ Bignoniaceae } \\
\hline 6 & $\begin{array}{l}\text { Catalpa bignonioides Walter } \\
\text { Катальпа бігнонієвидна }\end{array}$ & Інтродуцент & 14 \\
\hline \multicolumn{4}{|c|}{ Fabaceae } \\
\hline 7 & $\begin{array}{l}\text { Sophora japonica L. } \\
\text { Софора японська }\end{array}$ & Інтродуцент & 3 \\
\hline \multicolumn{4}{|c|}{ Fagaceae } \\
\hline 8 & $\begin{array}{l}\text { Quercus petraea (Mattuschka) Liebl. } \\
\text { Дуб скельний }\end{array}$ & Аборигенний вид & 1 \\
\hline 9 & $\begin{array}{l}\text { Quercus rubra L. (Q. borealis Michx.) } \\
\text { Дуб червоний, д. північний }\end{array}$ & Інтродуцент & 1 \\
\hline
\end{tabular}




\begin{tabular}{|c|c|c|c|}
\hline 1 & 2 & 3 & 4 \\
\hline \multicolumn{4}{|c|}{ Hippocastanaceae } \\
\hline 10 & $\begin{array}{l}\text { Aesculus hippocastanum L. } \\
\text { Кінський каштан звичайний }\end{array}$ & Інтродуцент & 20 \\
\hline \multicolumn{4}{|c|}{ Juglandaceae } \\
\hline 11 & $\begin{array}{l}\text { Juglans regia L. } \\
\text { Горіх волоський, г. грецький }\end{array}$ & Інтродуцент & 6 \\
\hline \multicolumn{4}{|c|}{ Moraceae } \\
\hline 12 & $\begin{array}{l}\text { Broussonetia papyrifera (L.) Vent. } \\
\text { Брусонеція паперова, паперове дерево }\end{array}$ & Інтродуцент & 1 \\
\hline \multicolumn{4}{|c|}{ Oleaceae } \\
\hline 13 & $\begin{array}{l}\text { Fraximus excelcior L. } \\
\text { Ясень звичайний }\end{array}$ & $\begin{array}{l}\text { Аборигенний } \\
\text { вид }\end{array}$ & 4 \\
\hline 14 & $\begin{array}{l}\text { Fraxinus pennsylvanica Marchchall (F. lanceolata } \\
\text { Borkh.) } \\
\text { Ясень пенсільванський (Я. ланцетолистий) }\end{array}$ & Інтродуцент & 2 \\
\hline \multicolumn{4}{|c|}{ Rosaceae } \\
\hline 15 & $\begin{array}{l}\text { Cerasus avium (L.) Moench. } \\
\text { Черешня }\end{array}$ & Аборигенний вид & 1 \\
\hline 16 & $\begin{array}{l}\text { Cerasus serrulata (Lindley) G. Don ex Loudon f. } \\
\text { roseo-plena Hort. (Prunus serrulata Lindley, Padus } \\
\text { serrulata (Lindl.) Sokolov) } \\
\text { Вишня сливолиста, сакура }\end{array}$ & Інтродуцент & 20 \\
\hline 17 & $\begin{array}{l}\text { Prunus cerasifera } \text { Ehrh. "Pissartii" (P. cerasifera } \\
\text { subsp. pissartii (Carrière ) Dostal = Prunus pissartii } \\
\text { Carrière) } \\
\text { Слива Піссарда }\end{array}$ & Інтродуцент & 6 \\
\hline \multicolumn{4}{|c|}{ Salicaceae } \\
\hline 18 & $\begin{array}{l}\text { Populus nigra L. } \\
\text { Тополя чорна, осокір }\end{array}$ & Аборигенний вид & 7 \\
\hline \multicolumn{4}{|c|}{ Tiliaceae } \\
\hline 19 & $\begin{array}{l}\text { Tilia cordata Mill. } \\
\text { Липа серцелиста }\end{array}$ & Аборигенний вид & 7 \\
\hline 20 & $\begin{array}{l}\text { Tilia platyphyllos Scop. } \\
\text { Липа широколиста }\end{array}$ & Аборигенний вид & 1 \\
\hline 21 & $\begin{array}{l}\text { Tilia } \times \text { vulgaris Hayne } \\
\text { (T. intermedia DC.) } \\
\text { Липа звичайна (л. середня, л. голландська) }\end{array}$ & $\begin{array}{l}\text { Природній гібрид } \\
\text { Tilia cordata } \times \text { T. } \\
\text { platyphyllos }\end{array}$ & 2 \\
\hline \multicolumn{3}{|c|}{ Всього } & 119 \\
\hline
\end{tabular}

У частині скверу Томаша Масарика, що прилягає до площі Дружби народів, росте три види лип (10 екземплярів), катальпа бігнонієвидна (14 екз.), ясен звичайний (2 екз.), по одному екземпляру дуба скельного і дуба червоного. Основний масив деревних насаджень складають кінський каштан звичайний (20 екз.), сакура (20 екз., 3 них 13 молодих дерев, що висаджені у 2018 році) та червонолиста слива Піссарда (6 екз., 3 яких 4 висаджені у 2018 році). У сквері на сьогодні також росте шість екземплярів самосіву горіху волоського, декоративність якого є сумнівною.

\section{Сквер «Університетський» (інша назва:} Святої Тетяни).

Розташований між будівлею ЗОДА та ректоратом ДВНЗ «Ужгородський національний університет» на перетині вулиць Тараса Шевченка і Юрія Гойди. Площа скверу 0,92 га. Про створення та історію відомо дуже мало. Згідно 3 конфігурацією та планом забудови територія передбачалась для забудови, оскільки точно такої ж конфігурації симетричний квартал 3 іншого боку будівлі ЗОДА був забудований житловими багатоповерхівками (Рис. 25, 26). 


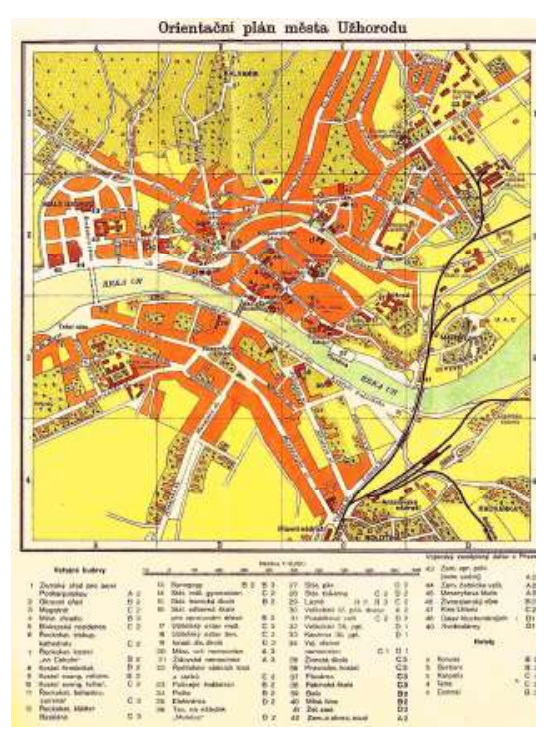

Рис. 25. План забудови мікрорайону «Малий Галагов» (https://rada-uzhgorod.gov.ua)

Fig. 25. Development plan of the urban district Malyi Galagov (https://rada-uzhgorod.gov.ua)

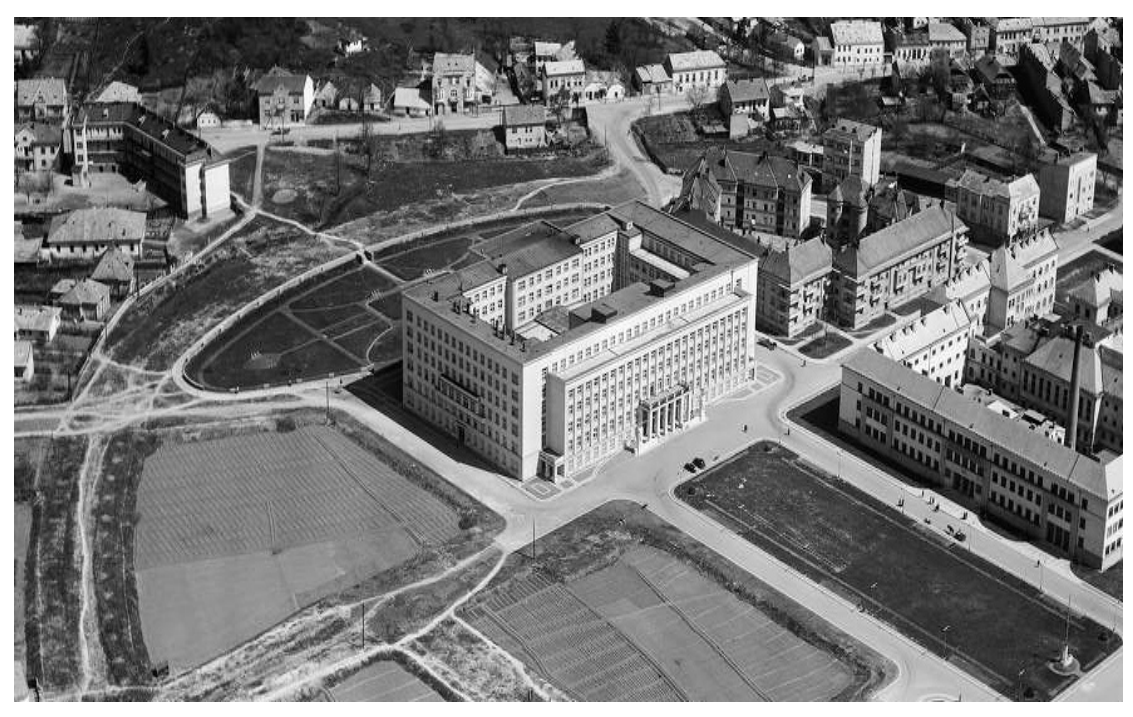

Рис. 26. Квартал «Малий Галагов», 1938 рік (http://am.umodernism.com/ua/about)

Fig. 26. Urban district «Malyi Galagov», 1938 (http://am.umodernism.com/ua/about)
Утім, генеральний задум не був реалізований. У радянські часи композиційним ядром скверу були обласна Дошка пошани та наочно-агітаційні стенди, а по периметру були висаджені кілька видів лип.

На теперішній час сквер знаходиться у досить занедбаному стані. На листопад 2020 року в ньому обраховано 14 видів деревних видів у кількості 53 особини (Табл. 4, Рис. 27). Основу посадок складають дерева липи двох видів: липа серцелиста та липа звичайна (Tilia $\times$ vulgaris) - 27 та шість особин відповідно. Голонасінні представлені сімома видами, що відносяться до п'яти родин. Три види $\epsilon$ аборигенними, чотири - інтродукованими.
Всього тут росте 11 екземплярів голонасінних рослин, переважно - в єдиному екземплярі, тільки широкогілочник східний у кількості п'яти особин.

Квіткові також представлені сімома видами, що відносяться до чотирьох родин. Всього тут росте 42 особини покритонасінних рослин. Серед них переважають аборигенні види, інтродуцентів два види. Клени гостролистий та клен-явір представлені по три екземпляри кожен, інші види - по одному.

За походженням інтродуковані види розділилися порівну: три - північноамериканського і три - китайсько-японського.

Таблиця 4. Видовий та кількісний склад дендрофлори скверу «Університетський»

Table 4. Species and quantitative composition of the dendroflora of the park square "Universyteskyi"

\begin{tabular}{|c|c|c|c|}
\hline $\begin{array}{l}\text { № } \\
\text { II/II }\end{array}$ & Таксон & Походження & $\begin{array}{c}\text { Загальна } \\
\text { кількість, екз. }\end{array}$ \\
\hline 1 & 2 & 3 & 4 \\
\hline \multicolumn{4}{|c|}{ PINOPHYTA } \\
\hline \multicolumn{4}{|c|}{ Ginkgoaceae } \\
\hline 1 & $\begin{array}{l}\text { Ginkgo biloba } \mathrm{L} . \\
\text { Гінкго дволопатеве }\end{array}$ & Інтродуцент & 1 \\
\hline \multicolumn{4}{|c|}{ Cupressaceae } \\
\hline 2 & $\begin{array}{l}\text { Platycladus orientalis (L.) Franco } \\
\text { Широкогілочник східний, біота східна }\end{array}$ & Інтродуцент & 5 \\
\hline 3 & $\begin{array}{l}\text { Thuja occidentalis L. } \\
\text { Туя західна }\end{array}$ & Інтродуцент & 1 \\
\hline
\end{tabular}




\begin{tabular}{|c|c|c|c|}
\hline 1 & 2 & 3 & 4 \\
\hline \multicolumn{4}{|c|}{ Pinaceae } \\
\hline 4 & $\begin{array}{l}\text { Abies alba Mill. } \\
\text { Ялиця біла }\end{array}$ & Аборигенний вид & 1 \\
\hline 5 & $\begin{array}{l}\text { Pinus sylvestris L. } \\
\text { Сосна звичайна }\end{array}$ & Аборигенний вид & 1 \\
\hline \multicolumn{4}{|c|}{ Taxodiaceae } \\
\hline 6 & $\begin{array}{l}\text { Cryptomeria japonica (Thunb. ex L. fil.) D. Don } \\
\text { Криптомерія японська }\end{array}$ & Інтродуцент & 1 \\
\hline \multicolumn{4}{|c|}{ Taxaceae } \\
\hline 7 & $\begin{array}{l}\text { Taxиs baccata } \mathrm{L} . \\
\text { Tис ягідний, негній-дерево }\end{array}$ & Аборигенний вид & 1 \\
\hline \multicolumn{4}{|c|}{ MAGNOLIOPHYTA } \\
\hline \multicolumn{4}{|c|}{ Aceraceae } \\
\hline 8 & $\begin{array}{l}\text { Acer negundo L. } \\
\text { Клен ясенолистий }\end{array}$ & Інтродуцент & 1 \\
\hline 9 & $\begin{array}{l}\text { Acer platanoides L. } \\
\text { Клен гостролистий }\end{array}$ & Аборигенний вид & 3 \\
\hline 10 & $\begin{array}{l}\text { Acer pseudoplatanus L. } \\
\text { Клен-явір }\end{array}$ & Аборигенний вид & 3 \\
\hline \multicolumn{4}{|c|}{ Betulaceae } \\
\hline 11 & $\begin{array}{l}\text { Carpinus betulus L. } \\
\text { Граб звичайний }\end{array}$ & Аборигенний вид & 1 \\
\hline \multicolumn{4}{|c|}{ Fabaceae } \\
\hline 12 & $\begin{array}{l}\text { Robinia pseudoacacia L. } \\
\text { Робінія звичайна }\end{array}$ & Інтродуцент & 1 \\
\hline \multicolumn{4}{|c|}{ Tiliaceae } \\
\hline 13 & $\begin{array}{l}\text { Tilia cordata Mill. } \\
\text { Липа серцелиста }\end{array}$ & Аборигенний вид & 27 \\
\hline 14 & $\begin{array}{l}\text { Tilia } \times \text { vulgaris Hayne }(T . \text { intermedia } \text { DC.) } \\
\text { Липа звичайна (л. середня, л. голландська) }\end{array}$ & $\begin{array}{c}\text { Природній гібрид } \\
\text { Tilia cordata } \times \\
\text { T. platyphyllos } \\
\end{array}$ & 6 \\
\hline \multicolumn{3}{|c|}{ Всього } & 53 \\
\hline
\end{tabular}

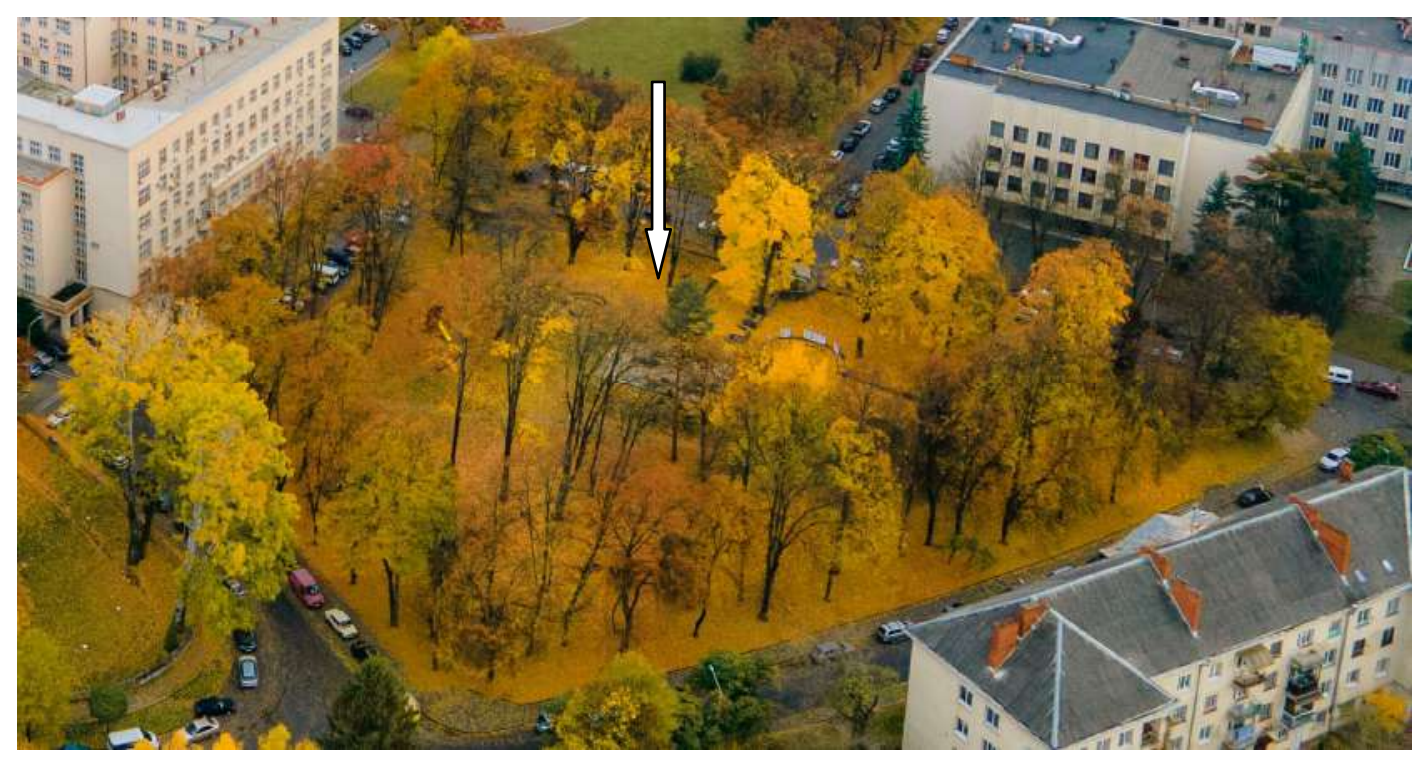

Рис. 27. Сучасний вигляд скверу «Університетський» (позначений стрілкою) (фото В. Трофименко)

Fig. 27. Modern view of the park square "Universyteskyi" (marked by arrow) (photo by V. Trofymenko) 
Сквер «Малий Галагов» (інша назва: сквер Франтішека Крупки).

На відміну від скверів «Університетський» та на пл. Народній, які сформувались на місці планованих під забудову котлованів, ділянка сучасного скверу «Малий Галагов» 3 самого початку проєктувалася як зелена зона (Рис. 25, 26).

На території скверу росте 22 види рослин, що відносяться до 10 родин, у кількості 67 особин (Табл. 5, Рис. 28). Голонасінні представлені двома родинами, що включають вісім видів. Найбільшою кількістю представлені сосна звичайна та кипарисовик Лавсона чотири та три особини відповідно. До покритонасінних відноситься вісім родин та 59 видів. Інтродуковані й аборигенні рослини представлені однаковою кількістю видів.

Таблиця 5. Видовий та кількісний склад дендрофлори скверу «Малий Галагов»

Table 5. Species and quantitative composition of the dendroflora of the park square "Malyi Galagov"

\begin{tabular}{|c|c|c|c|}
\hline $\begin{array}{l}\text { № } \\
\text { I/II }\end{array}$ & Таксон & Походження & $\begin{array}{c}\text { Загальна } \\
\text { кількість, екз. }\end{array}$ \\
\hline 1 & 2 & 3 & 4 \\
\hline \multicolumn{4}{|c|}{ PINOPHYTA } \\
\hline \multicolumn{4}{|c|}{ Cupressaceae } \\
\hline 1 & $\begin{array}{l}\text { Chamaecyparis lawsoniana (A. Murray) Parl. } \\
\text { Кипарисовик Лавсона }\end{array}$ & Інтродуцент & 3 \\
\hline 2 & $\begin{array}{l}\text { Thuja occidentalis L. } \\
\text { Туя західна }\end{array}$ & Інтродуцент & 2 \\
\hline 3 & $\begin{array}{l}\text { Thuja plicata D. Don. } \\
\text { Туя складчаста, т. велетенська }\end{array}$ & Інтродуцент & 1 \\
\hline \multicolumn{4}{|c|}{ Pinaceae } \\
\hline 4 & $\begin{array}{l}\text { Cedrus atlantica (Endl.) Carrière } \\
\text { Кедр атласький }\end{array}$ & Інтродуцент & 1 \\
\hline 5 & $\begin{array}{l}\text { Pinus nigra J.F. Arnold. } \\
\text { Сосна чорна }\end{array}$ & Інтродуцент & 1 \\
\hline 6 & $\begin{array}{l}\text { Pinus mugo Turra (P. mughus Scop.) } \\
\text { Сосна гірська, с. жереп }\end{array}$ & $\begin{array}{c}\text { Аборигенний } \\
\text { вид } \\
\end{array}$ & 1 \\
\hline 7 & $\begin{array}{l}\text { Pinus sylvestris L. } \\
\text { Сосна звичайна }\end{array}$ & $\begin{array}{l}\text { Аборигенний } \\
\text { вид }\end{array}$ & 4 \\
\hline 8 & $\begin{array}{l}\text { Pseudotsuga menziesii (Mirbel) Franco } \\
\text { Псевдотсуга Мензіса, дугласія тисолиста }\end{array}$ & Інтродуцент & 1 \\
\hline \multicolumn{4}{|c|}{ MAGNOLIOPHYTA } \\
\hline \multicolumn{4}{|c|}{ Aceraceae } \\
\hline 9 & $\begin{array}{l}\text { Acer platanoides } \mathrm{L} \text {. } \\
\text { Клен гостролистий }\end{array}$ & $\begin{array}{l}\text { Аборигенний } \\
\text { вид }\end{array}$ & 1 \\
\hline 10 & $\begin{array}{l}\text { Acer pseudoplatanus L. } \\
\text { Клен-явір }\end{array}$ & $\begin{array}{l}\text { Аборигенний } \\
\text { вид }\end{array}$ & 1 \\
\hline \multicolumn{4}{|c|}{ Caprifoliaceae } \\
\hline 11 & $\begin{array}{l}\text { Sambucus nigra L. } \\
\text { Бузина чорна }\end{array}$ & $\begin{array}{c}\text { Аборигенний } \\
\text { вид }\end{array}$ & 6 \\
\hline \multicolumn{4}{|c|}{ Corylaceae } \\
\hline 12 & $\begin{array}{l}\text { Corylus avellana } \mathrm{L} \text {. } \\
\text { Ліщина звичайна }\end{array}$ & $\begin{array}{c}\text { Аборигенний } \\
\text { вид }\end{array}$ & 1 \\
\hline \multicolumn{4}{|c|}{ Fabaceae } \\
\hline 13 & $\begin{array}{l}\text { Cercis siliquastrum L. } \\
\text { Церцис європейський, ц. стручковий }\end{array}$ & Інтродуцент & 1 \\
\hline 14 & $\begin{array}{l}\text { Robinia pseudoacacia L. } \\
\text { Робінія звичайна }\end{array}$ & Інтродуцент & 3 \\
\hline \multicolumn{4}{|c|}{ Oleaceae } \\
\hline 15 & $\begin{array}{l}\text { Syringa vulgaris L. } \\
\text { Бузок звичайний }\end{array}$ & Інтродуцент & 6 \\
\hline
\end{tabular}




\begin{tabular}{|c|c|c|c|}
\hline 1 & 2 & 3 & 4 \\
\hline \multicolumn{4}{|c|}{ Rosaceae } \\
\hline 16 & $\begin{array}{l}\text { Cerasus serrulata (Lindley) G. Don ex Loudon f. roseo-plena } \\
\text { Hort. (Prunus serrulata Lindley, Padus serrulata (Lindl.) } \\
\text { Sokolov) } \\
\text { Вишня сливолиста, сакура }\end{array}$ & Інтродуцент & 3 \\
\hline 17 & $\begin{array}{l}\text { Malus niedzwetzkyana Dieck ex Koehne } \\
\text { Яблуня Недзвецького }\end{array}$ & Інтродуцент & 3 \\
\hline 18 & $\begin{array}{l}\text { Prunus cerasifera } \text { Ehrh. "Pissartii" (P. cerasifera subsp. } \\
\text { pissartii (Carrière ) Dostal = Prunus pissartii Carrière) } \\
\text { Слива Піссарда }\end{array}$ & Інтродуцент & 2 \\
\hline \multicolumn{4}{|c|}{ Salicaceae } \\
\hline 19 & $\begin{array}{l}\text { Populus alba L. } \\
\text { Тополя біла }\end{array}$ & $\begin{array}{l}\text { Аборигенний } \\
\text { вид }\end{array}$ & 1 \\
\hline 20 & $\begin{array}{l}\text { Populus nigra L. } \\
\text { Тополя чорна, осокір }\end{array}$ & $\begin{array}{l}\text { Аборигенний } \\
\text { вид }\end{array}$ & 6 \\
\hline 21 & $\begin{array}{l}\text { Populus } \times \text { canescens (Aiton) J.E. Smith. } \\
\text { Тополя сірувата }\end{array}$ & $\begin{array}{l}\text { Гібрид Populus } \\
\quad \text { alba } \times P \text {. } \\
\text { tremula }\end{array}$ & 5 \\
\hline \multicolumn{4}{|c|}{ Tiliaceae } \\
\hline 22 & $\begin{array}{l}\text { Tilia cordata Mill. } \\
\text { Липа серцелиста }\end{array}$ & $\begin{array}{l}\text { Аборигенний } \\
\text { вид }\end{array}$ & 14 \\
\hline \multicolumn{3}{|c|}{ Всього } & 67 \\
\hline
\end{tabular}

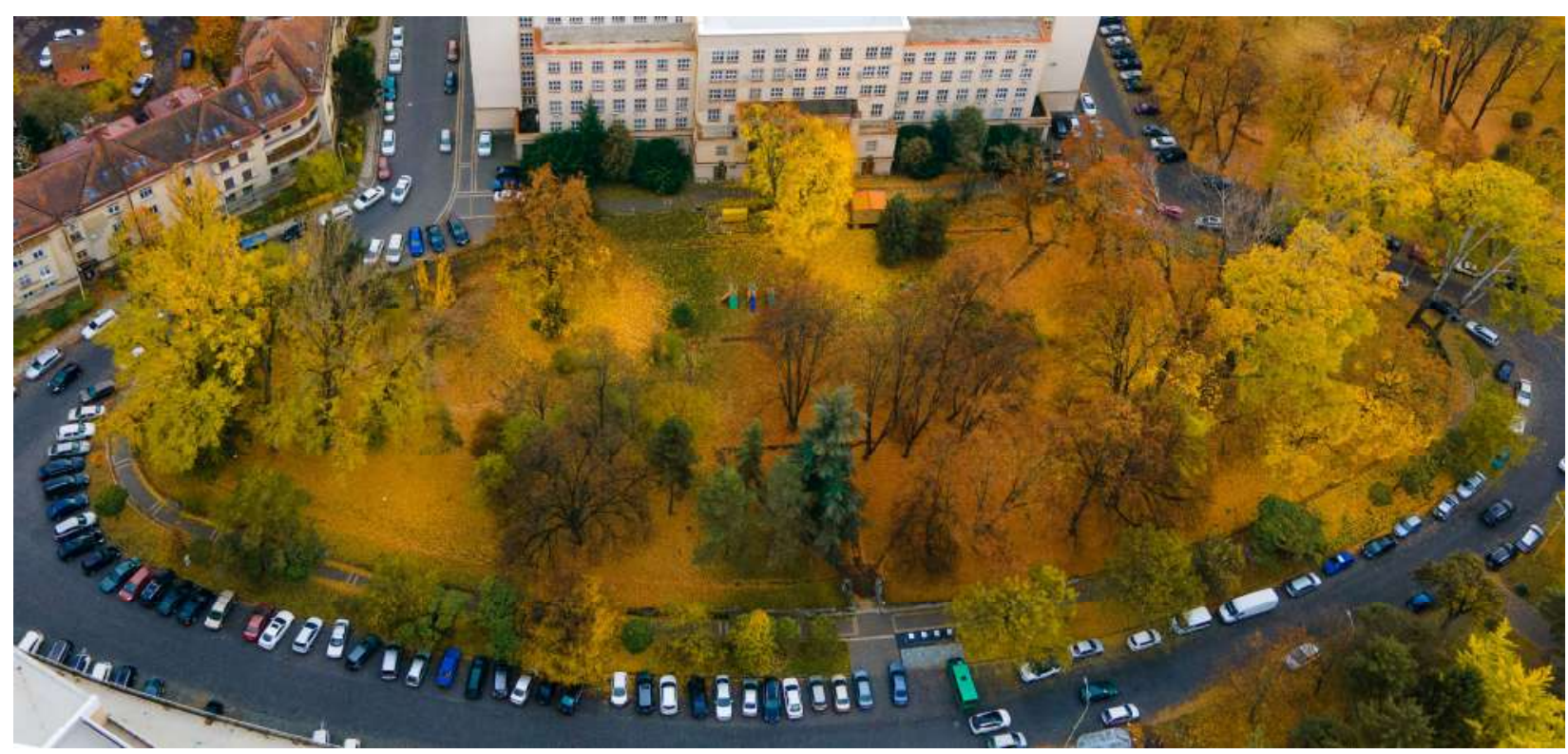

Рис. 28. Сучасний вигляд скверу «Малий Галагов» (фото В. Трофименко)

Fig. 28. Modern view of the park square "Malyi Galagov" (photo by V. Trofymenko)

Основу деревостану скверу складають дерева липи серцелистої (14 особин) та тополі: біла, чорна і сірувата (12 особин) (Рис. 29). Тополі, що ростуть тут, є одними 3 найбільших дерев як в мікрорайоні «Малий Галагов», так і в Ужгороді в цілому. Так, розміри тополі чорної коливаються в межах 26,6-33,6 м висотою та від 2,53 до 5,8 м в обхваті (діаметр від 0,8 до 1,85 м), тополі сіруватої в межах 23-29,0 м висотою та від 1,5 до 3 м у діаметрі. На жаль, у тополь досить поверхнева коренева система і при таких розмірах вони легко вивертаються з коренем під час сильних вітрів та снігопадів. Один із таких великих екземплярів тополі сіруватої вивернувся 3 коренем узимку 2017 року. На території скверу росте, мабуть, найстаріший i найвищий у місті екземпляр бузини чорної висотою 10,2 м і діаметром 0,78 м (Рис. 30). 


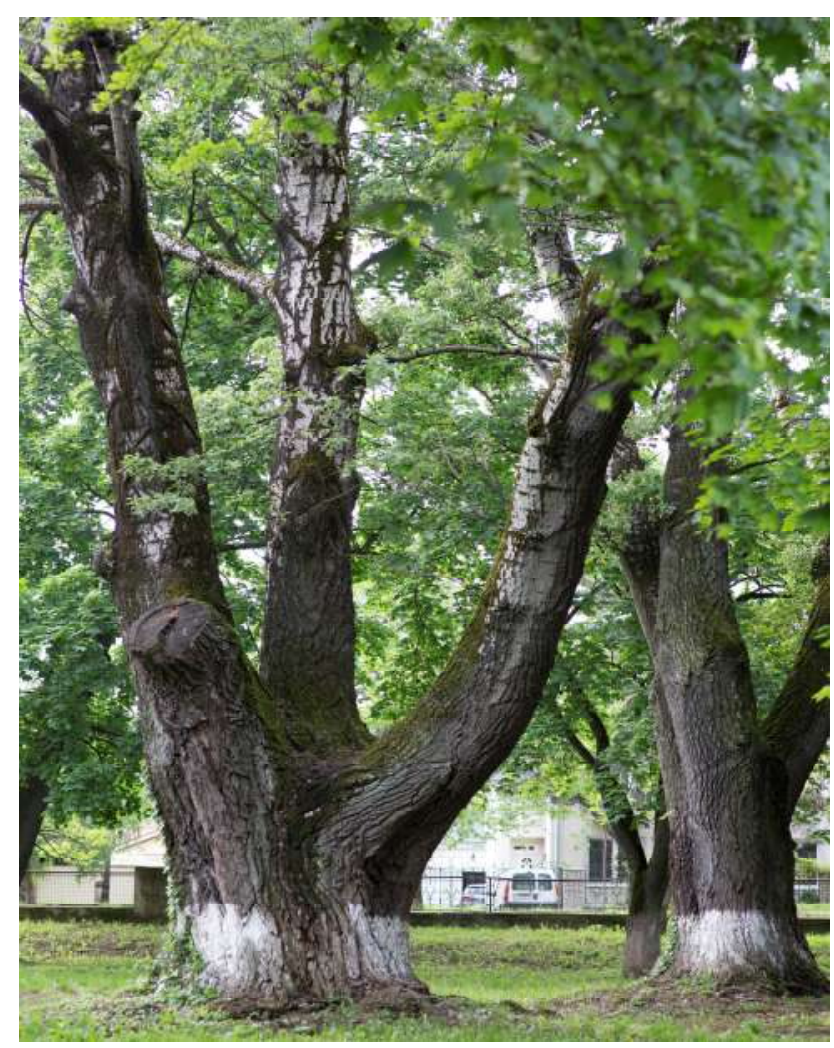

Рис. 29. Дерева тополі сіруватої (Рорulus $\times$ canescens) у сквері «Малий Галагов» (фото Я. Гасинець)

Fig. 29. The grey poplar (Populus $\times$ canescens) (photo by Ya. Hasynets)

У парку використані типові для озеленення мікрорайону «Малий Галагов» види: сакура, яблуня Недзвецького, слива Піссарда. Це одні з найперших посадок, тому ці, нині вже старі дерева, знаходяться у незадовільному

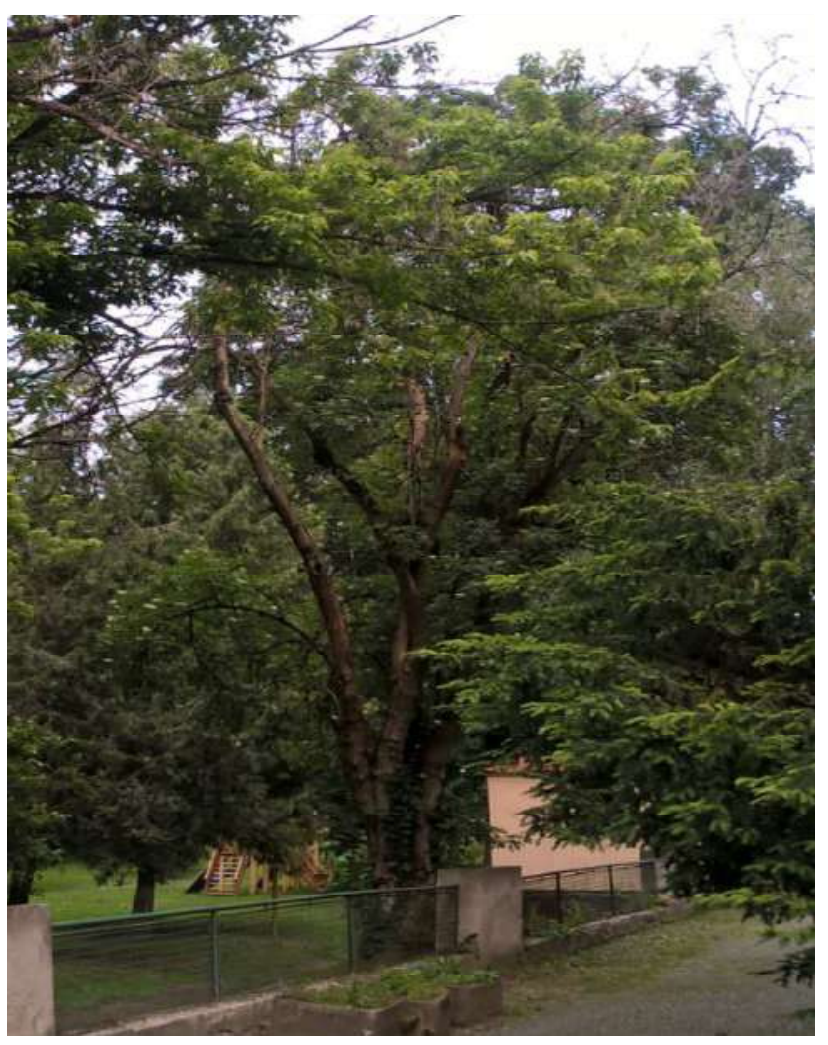

Рис. 30. Одне $з$ найстаріших у місті дерев бузини чорної (Sambucus nigra) росте у сквері «Малий Галагов» (фото I. Бесеганич)

Fig. 30. The black elder (Sambucus nigra) (photo by I. Besehanych)

стані. В останні роки декілька екземплярів дерев цих видів всохли і були вилучені.

\section{Сквер на вулиці Небесної сотні.}

Це невеликий сквер трикутної форми, що розташований на розі вулиць Небесної Сотні та Івана Крилова (Табл. 6, Рис. 31).

Таблиця 6. Видовий та кількісний склад дендрофлори скверу на вулиці Небесної Сотні

Fig. 6. Species and quantitative composition of the dendroflora of the park square on the Nebesna Sotnia street

\begin{tabular}{|c|c|c|c|}
\hline $\begin{array}{l}\text { № } \\
\text { ПI/II }\end{array}$ & Таксон & Походження & $\begin{array}{c}\text { Загальна } \\
\text { кількість, екз. }\end{array}$ \\
\hline \multicolumn{4}{|c|}{ PINOPHYTA } \\
\hline \multicolumn{4}{|c|}{ Cupressaceae } \\
\hline 1 & $\begin{array}{l}\text { Platycladus orientalis (L.) Franco Широкогілочник } \\
\text { східний, біота східна }\end{array}$ & Інтродуцент & 7 \\
\hline 2 & $\begin{array}{l}\text { Thuja plicata D. Don. } \\
\text { Туя складчаста, т. велетенська }\end{array}$ & Інтродуцент & 1 \\
\hline \multicolumn{4}{|c|}{ MAGNOLIOPHYTA } \\
\hline \multicolumn{4}{|c|}{ Oleaceae } \\
\hline 3 & $\begin{array}{l}\text { Ligustrum vulgare L. } \\
\text { Бирючина звичайна }\end{array}$ & Аборигенний вид & 1 \\
\hline \multicolumn{3}{|c|}{ Всього } & 9 \\
\hline
\end{tabular}




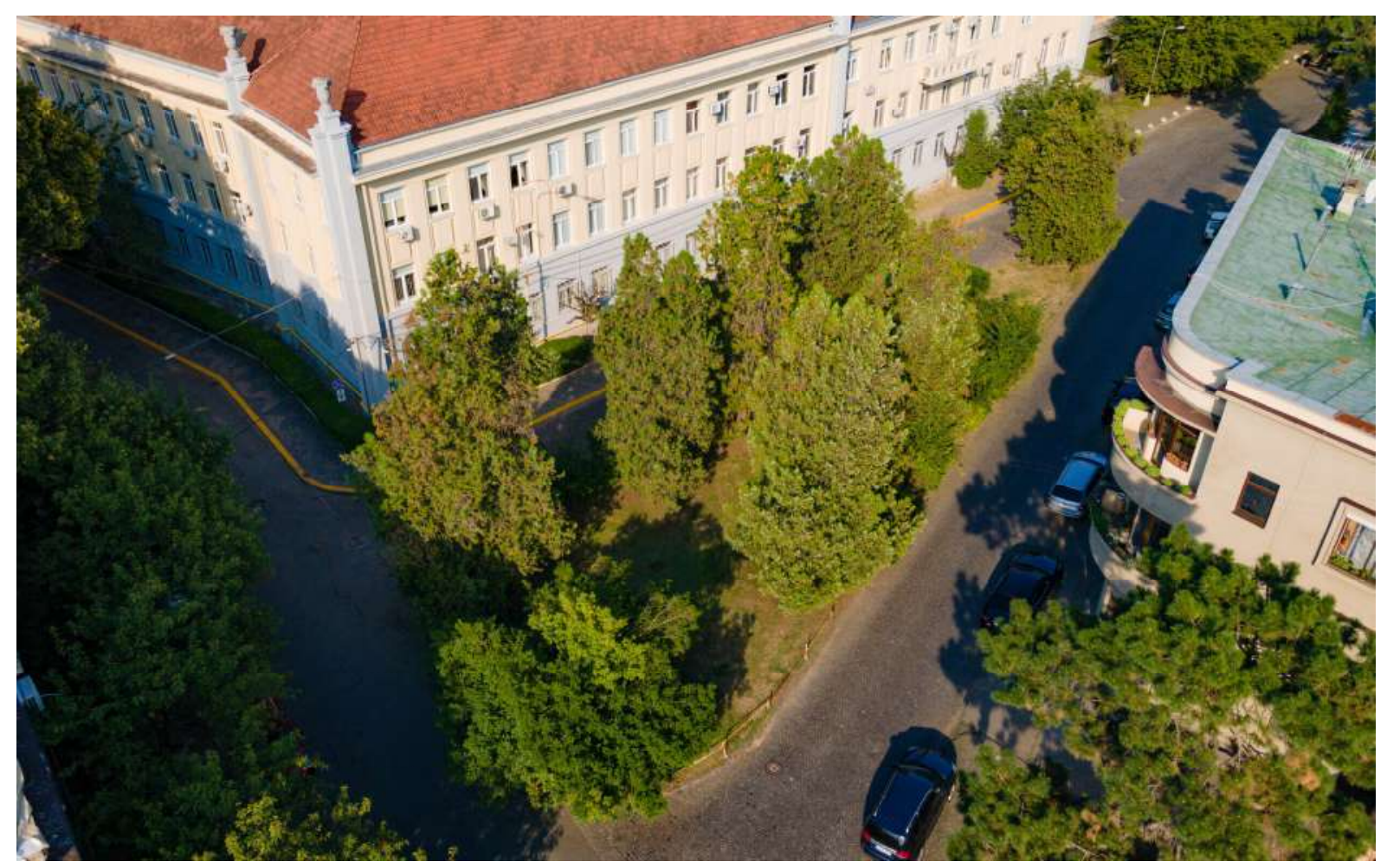

Рис. 31. Сучасний вигляд скверу на вулиці Небесної Сотні (фото В. Трофименко)

Fig. 31. Modern view of the square park on the Nebesna Sotnia street (photo by V. Trofymenko)

Зелені насадження в ньому представлені, в основному, старими деревами широкогілочника східного висотою 7,8-10,4 м та бирючиною звичайною. Остання використана як солітер (дерево висотою 5,2 м) та в якості бордюру по периметру скверу.

\section{Сквер на площі Олександра Пушкіна.}

До 1930 року через площу протікав рукав річки Уж - Малий Уж, який тут зливався 3 головним руслом (Рис. 32). Чехословацька влада, дбаючи про належний епідеміологічний стан, ліквідувала Малий Уж, запустивши його в каналізаційний колектор. Так, у 1932 році з'являється площа, названа в честь спортивного діяча, засновника спортивно-патріотичної організації «Сокіл» Мирослава Тирша, в центрі якої йому було встановлено пам'ятник (Kobal 2003 ) (Рис. 33). Згодом на площі були висаджені хвойні дерева (Рис. 34, 35). У радянські часи площа була прикрашена квітниками прямокутної форми. Тут росло тільки одне дерево ялини колючої, яке збереглось і донині.

Сквер невеликий за розмірами $(0,08$ га), відповідно й кількість рослин незначна (Табл. 7 , Рис. 36). Серед них три дерева сакури (в тому числі одна плакучої форми). Усі рослини, крім ялини колючої, було висаджено вже за часів незалежності України.

Таблиця 7. Видовий та кількісний склад дендрофлори скверу на площі Олександра Пушкіна

Table 7. Species and quantitative composition of the dendroflora of the square park on Alexander Pushkin square

\begin{tabular}{|c|c|c|c|}
\hline $\begin{array}{c}\text { № } \\
\text { п/п }\end{array}$ & Таксон & Поширення & $\begin{array}{c}\text { Загальна } \\
\text { кількість, екз. }\end{array}$ \\
\hline $\mathbf{1}$ & $\mathbf{2}$ & $\mathbf{3}$ & $\mathbf{4}$ \\
\hline \multicolumn{3}{|c|}{ PINOPHYTA } \\
\hline \multicolumn{4}{|c|}{ Cupressaceae } \\
\hline 1 & $\begin{array}{l}\text { Juniperus chinensis "Blue Alps” } \\
\text { Ялівець китайський “Blue Alps” }\end{array}$ & Інтродуцент & $\mathbf{1}$ \\
\hline 2 & Juniperus sp. & Інтродуцент & 7 \\
\hline
\end{tabular}




\begin{tabular}{|c|c|c|c|}
\hline 1 & 2 & 3 & 4 \\
\hline \multicolumn{4}{|c|}{ Pinaceae } \\
\hline 3 & $\begin{array}{l}\text { Picea pungens Engelm. } \\
\text { Ялина колюча }\end{array}$ & Інтродуцент & 1 \\
\hline 4 & $\begin{array}{l}\text { Pinus nigra J.F. Arnold. } \\
\text { Сосна чорна }\end{array}$ & Інтродуцент & 2 \\
\hline \multicolumn{4}{|c|}{ Rosaceae } \\
\hline 5 & $\begin{array}{l}\text { Cerasus serrulata (Lindley) G. Don ex Loudon f. roseo- } \\
\text { plena Hort. (Prunus serrulata Lindley, Padus serrulata } \\
\text { (Lindl.) Sokolov) } \\
\text { Вишня сливолиста, сакура }\end{array}$ & Інтродуцент & 3 \\
\hline \multicolumn{3}{|c|}{ Всього } & 14 \\
\hline
\end{tabular}
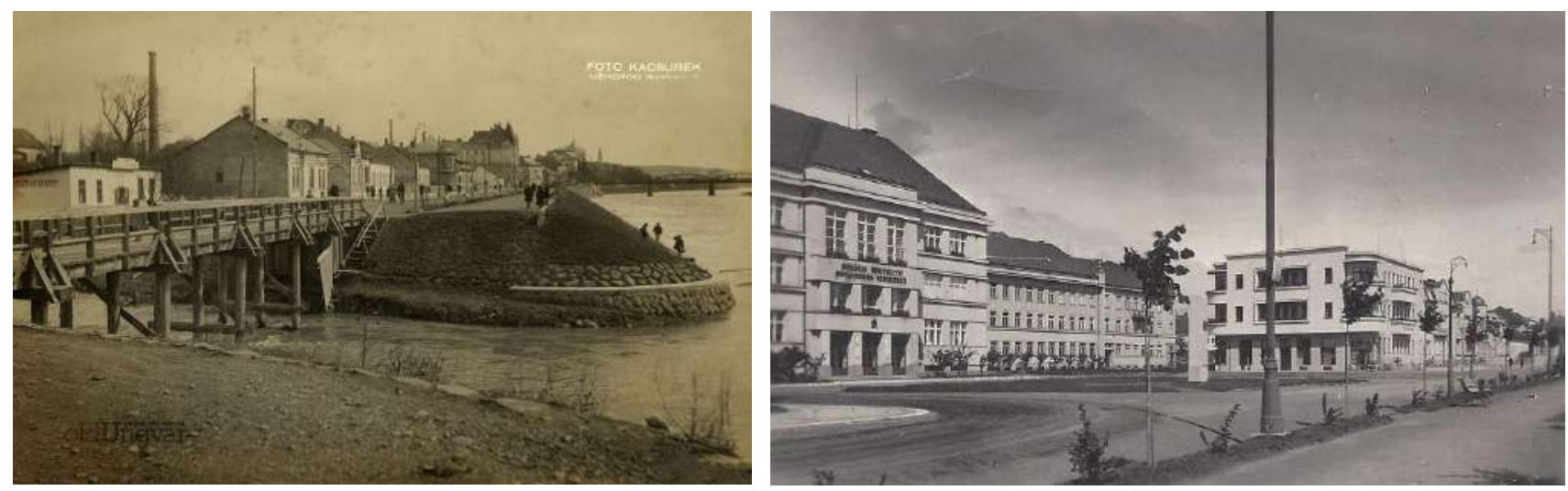

Рис. 32. 1931 р., Малий Уж впадає в основне русло. Тепер пл. Олександра Пушкіна. Фото Качурек. Колекція: Jozef Illesh (https://www.facebook.com/transcarpathian.heritage)

Fig. 32. 1931, Malyi Uzh river flows into the main riverbed. Now it's the Alexander Pushkin square. Photo by Kachurek. Collection: Jozef Illesh (https://www.facebook.com/transcarpathian.heritage)
Рис. 33. Набережна Ужа та Тиршова площа (нині пл. Олександра Пушкіна) в Ужгороді в 1932$1938 \mathrm{pp}$.

(https://www.facebook.com/transcarpathian.heritage)

Fig. 33. Uzh river Embankment and Tyrshova square (now it's the Alexander Pushkin square) in Uzhhorod in 1932-1938.

(https://www.facebook.com/transcarpathian.heritage)

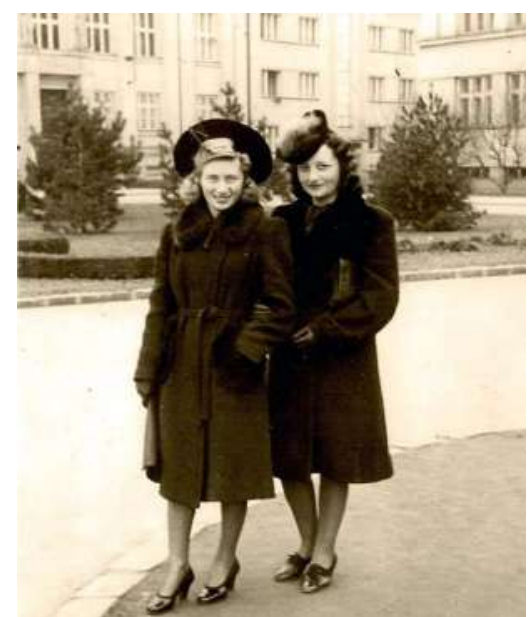

Рис. 34. Площа М. Тирша (сучасна Олександра Пушкіна) у 1937 році (http://ungvar.vox.com.ua/ua.html)

Fig. 34. M. Tyrsha square (now it's the Alexander Pushkin square) in 1937 (http://ungvar.vox.com.ua/ua.html)

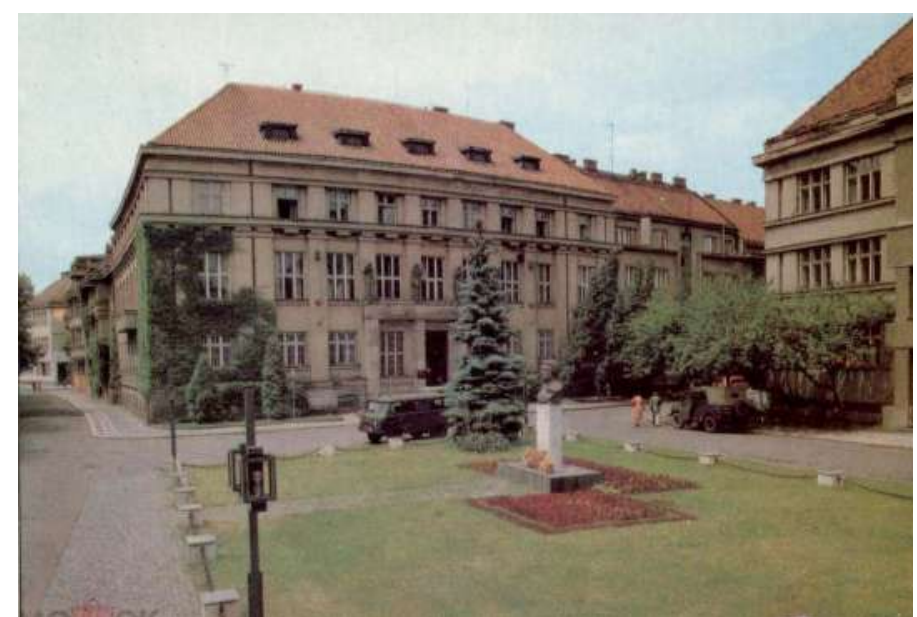

Рис. 35. Площа Олександра Пушкіна, 1990 р. Поштова листівка

Fig. 35. Alexander Pushkin square, 1990. Postcard 


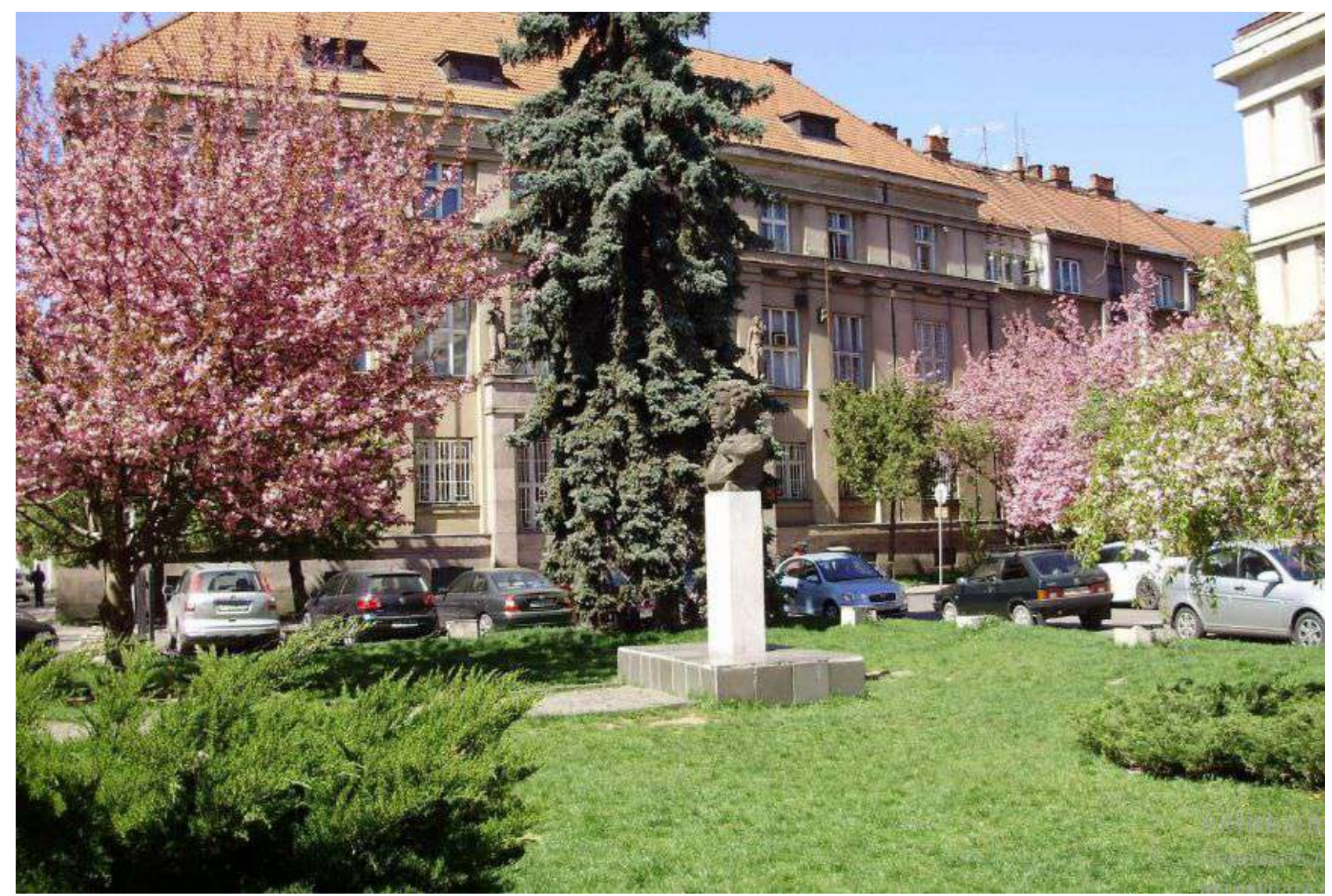

Рис. 36. Сучасний вигляд площі Олександра Пушкіна (https://wikimapia.org/21733631/be/Бюст-А-CПушкіну)

Fig. 36. Modern view of the Alexander Pushkin square (https://wikimapia.org/21733631/be/Бюст-А-CПушкіну)

Загалом на сьогодні в парках і скверах мікрорайону «Малий Галагов» зафіксовано 76 деревно-чагарникових видів, що відносяться до 26 родин, загальною кількістю 498 екземплярів. Половина 3 виявленого видового складу (38 видів) $€$ інтродуцентами, інша половина, відповідно - аборигенні види. Але за кількістю екземплярів більшість рослин належать до інтродуцентів - 337 особин $(67,7 \%)$, особини аборигенних порід складають менше третини 161 екземпляр (32,3\%) (Табл. 8).

За таксономічним складом у паркових насадженнях та скверах виявлено 21 вид голонасінних 3 п'яти родин у кількості 119 особин. Більшість із них $є$ інтродуцентами - 14 видів або $66,7 \%, 7$ видів - аборигенними $(32,3 \%)$. Щодо кількості екземплярів, то розподіл майже рівний - 64 особини $(53,8 \%) \epsilon$ інтродуцентами, $55(46,2) \%$ - аборигенними видами.

Покритонасінні представлені 55 деревночагарниковими видами 321 родини у кількості
379 екземплярів. На відміну від голонасінних, більшість видів квіткових, що ростуть у скверах і парках мікрорайону «Малий Галагов» - 31 вид $(56,4 \%)$ є аборигенними, 24 види (43,6\%) інтродуцентами. А от щодо кількості екземплярів, переважають інтродуценти - 249 особин (65,7\%), аборигенних видів 130 особин (343,3\%). Щодо походження інтродуцентів, то серед голонасінних переважають північноамериканські види, серед покритонасінних китайсько-японські.

У цілому, парки і сквери мікрорайону займають площу 5,0727 га. Найбільшими за розмірами $\epsilon$ партер на площі Народній (1,5704 га) та сквер «Малий Галагов» $(1,12$ га). Три сквери - ім. Героїв Майдану, на площі Народній (колишній сад троянд) та імені Томаша Масарика - займають майже однакову площу - 0,55-0,57 га. Сквери на вулиці Небесної сотні, на площі Олександра Пушкіна та дендросад Лаудона мають найменші площі $(0,08-0,1423)$. 
Таблиця 8. Таксономічний та кількісний склад парків і скверів мікрорайону «Малий Галагов»

Table 8. Taxonomic and quantitative composition of parks and square parks of the urban district "Malyi Galagov"

\begin{tabular}{|c|c|c|c|c|c|c|c|c|c|c|c|c|}
\hline \multirow[b]{2}{*}{$\begin{array}{l}\text { № } \\
\text { ПI/II }\end{array}$} & \multirow[b]{2}{*}{ Найменування об'скту } & \multirow[b]{2}{*}{$\begin{array}{l}\text { Площа, } \\
\text { га }\end{array}$} & \multicolumn{5}{|c|}{ Кількість видів } & \multicolumn{5}{|c|}{ Кількість особин } \\
\hline & & & $\begin{array}{l}\stackrel{0}{0} \\
\stackrel{0}{0} \\
\text { An }\end{array}$ & 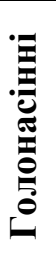 & 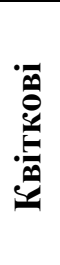 & 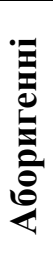 & 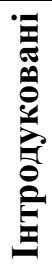 & $\begin{array}{l}\stackrel{0}{0} \\
\stackrel{0}{0} \\
\text { An }\end{array}$ & 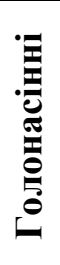 & 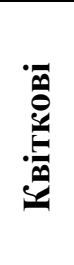 & 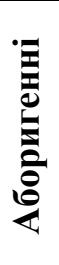 & 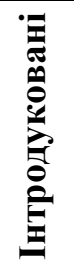 \\
\hline 1 & Дендросад Лаудона & 0,1423 & 10 & 8 & 2 & 2 & 8 & 10 & 8 & 2 & 2 & 8 \\
\hline 2 & Сквер ім. Героїв Майдану & 0,55 & 20 & 4 & 16 & 7 & 13 & 61 & 7 & 54 & 30 & 31 \\
\hline 3 & Партер на площі Народній & 1,5704 & & 2 & 3 & & & & & & & \\
\hline 4 & $\begin{array}{c}\text { Сквер на площі Народній } \\
\text { (колишній сад троянд) }\end{array}$ & 0,55 & 24 & 5 & 19 & 4 & 20 & 133 & 16 & 117 & 22 & 111 \\
\hline 5 & Сквер імені Томаша Масарика & 0,57 & 21 & 4 & 17 & 10 & 11 & 119 & 22 & 97 & 32 & 87 \\
\hline 6 & Сквер «Університетський» & 0,4 & 14 & 7 & 7 & 8 & 6 & 53 & 11 & 42 & 43 & 10 \\
\hline 7 & Сквер «Малий Галагов» & 1,12 & 22 & 8 & 14 & 10 & 12 & 67 & 14 & 53 & 40 & 27 \\
\hline 8 & $\begin{array}{l}\text { Сквер на вулиці Небесної } \\
\text { сотні }\end{array}$ & 0,09 & 3 & 2 & 1 & 1 & 2 & 9 & 8 & 1 & 1 & 8 \\
\hline 9 & $\begin{array}{c}\text { Сквер на площі Олександра } \\
\text { Пушкіна }\end{array}$ & 0,08 & 5 & 4 & 1 & - & 5 & 14 & 11 & 3 & - & 14 \\
\hline
\end{tabular}

Найбільшою видовою насиченістю за співвідношенням «площа - кількість видів» характеризується сад Лаудона. Сквери ім. Героїв Майдану, на площі Народній та імені Томаша Масарика характеризуються наявністю приблизно однакової кількості видів (20-24 види). У чотирьох скверах переважають види квіткових, у трьох - голонасінні, в одному квіткові і голонасінні представлені однаковою кількістю видів. За кількістю особин у п'яти парках і скверах суттєво переважають квіткові рослини, в трьох - голонасінні.

В усіх парках i скверах, крім скверу «Університетський», за кількістю видів домінують інтродуковані рослини. Майже та сама ситуація і з кількістю особин: тільки в скверах «Університетський» та «Малий Галагов» переважають аборигенні рослини.

Нині найбільш повно відповідають первісному плануванню та асортименту три сквери - ім. Героїв Майдану, імені Томаша Масарика та «Малий Галагов».

Також було проаналізовано життєвий стан зелених насаджень парків i скверів мікрорайону «Малий Галагов» (Табл. 9). У сквері ім. Героїв Майдану виявлено сім дерев у задовільному стані, що становить $11,5 \%$. У сквері ім. Томаша Масарика нараховано 27 фаутних дерев $(22,7 \%) .3$ них тільки одне дерево ялини європейської має незадовільний стан, інші - задовільний. Більшість хвойних, що ростуть у сквері, висаджені дуже щільно, тому затінюють один одного, що призводить до відмирання нижніх гілок і спотворення форми крони. У дерев катальп бігнонієвидних, крім відмирання гілок, наявні грибкові хвороби.

У сквері «Університетський» виявлено сім фаутних дерев (13,2\%), з них одне відмирає, чотири - у незадовільному стані, два - у задовільному. Більшість фаутних дерев - це голонасінні, які ростуть під пологом великих дерев і нестача сонячного світла призводить до погіршення їх життєвого стану.

У сквері «Малий Галагов» нами обраховано 17 фаутних дерев, що становить 25,4\% від загальної кількості. П'ять дерев знаходяться у задовільному стані, вісім - у незадовільному та чотири відмирають. Така велика кількість фаутних дерев пов'язана 3 двома причинами: частина дерев досягли свого граничного віку (сакури, слива Піссарда, тополі), а частина знаходиться в пригніченому стані внаслідок затінення (сосни).

У сквері на площі Олександра Пушкіна виявлено одне дерево сакури у незадовільному стані: наявні плодові тіла трутовика, засихає частина гілок. 
Таблиця 9. Характеристика стану зелених насаджень парків і скверів мікрорайону «Малий Галагов»

Table 9. Characteristics of the green plantations status in the square parks of the "Malyi Galagov" urban district

\begin{tabular}{|c|c|c|c|c|c|c|c|c|c|c|c|c|c|c|c|c|c|c|c|c|c|}
\hline \multirow{5}{*}{$\begin{array}{l}\text { № } \\
\Pi / \Pi\end{array}$} & \multirow{5}{*}{ Вид } & \multicolumn{4}{|c|}{$\begin{array}{c}\text { Сквер ім. Героїв } \\
\text { Майдану }\end{array}$} & \multicolumn{4}{|c|}{$\begin{array}{c}\text { Сквер ім. Томаша } \\
\text { Масарика }\end{array}$} & \multicolumn{4}{|c|}{$\begin{array}{c}\text { Сквер } \\
\text { «Університетський» }\end{array}$} & \multicolumn{4}{|c|}{$\begin{array}{c}\text { Сквер «Малий } \\
\text { Галагов» }\end{array}$} & \multicolumn{4}{|c|}{$\begin{array}{c}\text { Сквер на площі } \\
\text { Олександра Пушкіна }\end{array}$} \\
\hline & & \multicolumn{20}{|c|}{ стан } \\
\hline & & 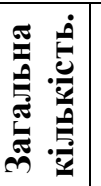 & 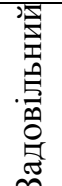 & 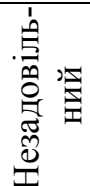 & 芯 & 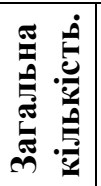 & 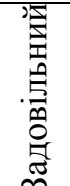 & 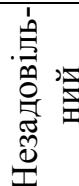 & 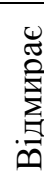 & 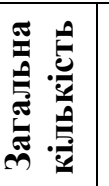 & 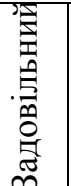 & 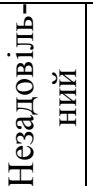 & 离 & 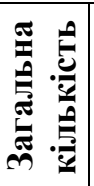 & 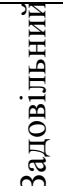 & 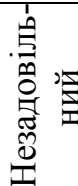 & 离 & 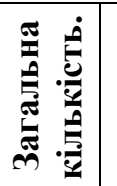 & 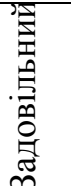 & 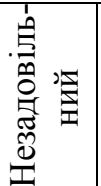 & 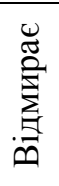 \\
\hline & & \multicolumn{20}{|c|}{ Кількість, шт. } \\
\hline & & 61 & 7 & - & - & 119 & 26 & 1 & - & 53 & 2 & 4 & 1 & 67 & 5 & 8 & 4 & 14 & - & 1 & - \\
\hline 1 & Гінкго дволопатеве & & & & & & & & & & 1 & & & & & & & & & & \\
\hline 2 & Криптомерія японська & & & & & & & & & & & 1 & & & & & & & & & \\
\hline 3 & $\begin{array}{l}\text { Широкогілочник } \\
\text { східний }\end{array}$ & & & & & & & & & & & 3 & & & & & 1 & & & & \\
\hline 4 & Туя західна & & 1 & & & & & & & & 1 & & & & & & & & & & \\
\hline 5 & Ялина європейська & & & & & & 6 & 1 & & & & & & & & & & & & & \\
\hline 6 & Сосна гірська, с. жереп & & & & & & & & & & & & & & 1 & & & & & & \\
\hline 7 & Сосна звичайна & & & & & & & & & & & & & & 2 & & & & & & \\
\hline 8 & Псевдотсуга Мензіса & & 1 & & & & 9 & & & & & & & & & 1 & & & & & \\
\hline 9 & $\begin{array}{l}\text { Катальпа } \\
\text { бігнонієвидна }\end{array}$ & & & & & & 10 & & & & & & & & & & & & & & \\
\hline 10 & Софора японська & & & & & & 1 & & & & & & & & & & & & & & \\
\hline 11 & $\begin{array}{l}\text { Кінський каштан } \\
\text { звичайний }\end{array}$ & & 3 & & & & & & & & & & & & & & & & & & \\
\hline 12 & Сакура & & & & & & & & & & & & & & & & 1 & & 1 & & \\
\hline 13 & Слива Піссарда & & & & & & & & & & & & & & & 1 & 1 & & & & \\
\hline 14 & Липа серцелиста & & & & & & & & & & & & & & & 1 & & & & & \\
\hline 15 & Клен гостролистий & & & & & & & & & & & & 1 & & 1 & & & & & & \\
\hline 16 & Клен цукристий & & 2 & & & & & & & & & & & & & & & & & & \\
\hline 17 & Бузина чорна & & & & & & & & & & & & & & & 1 & & & & & \\
\hline 18 & Тополя чорна, осокір & & & & & & & & & & & & & & 1 & 3 & & & & & \\
\hline 19 & Тополя сірувата & & & & & & & & & & & & & & & 1 & 1 & & & & \\
\hline
\end{tabular}


В інших скверах фаутних дерев не виявлено. У сквері на вулиці Небесної сотні дерева широкогілочника східного у хорошому стані, але втратили декоративність (втрата декоративності 3 віком - загальна риса для цього виду). У саді Лаудона двадцять років тому впало одне 3 дерев болотного кипарису. При падінні була зламана частина крони магнолії Суланжа. Незважаючи на це, магнолія знаходиться в хорошому стані, цвіте і плодоносить.

Таким чином, найпоширенішими пошкодженнями, які були виявлені, є всихання гілок, суховершинення, дуплистість, нарости, пошкодження комахами-шкідниками та грибами.

Загалом, сьогодні всі парки та сквери мікрорайону потребують невідкладних заходів благоустрою, а більшість - термінової реконструкції, зокрема, підсадки дерев, вилучення малоцінних самосівів, упорядкування крон тощо. Одним із першочергових заходів є фахова розробка проєктів ландшафтного дизайну та поетапного плану дій стосовного кожного 3 парків і скверів. Варто зазначити, що зелені насадження рівноцінно 3 архітектурою формують загальний вигляд одного з найбільш туристично привабливих мікрорайонів м. Ужгорода, виступаючи не менш значимими поряд 3 будівлями персонажами візуального образу історичного міста, за якими сьогодні Ужгород впізнаваний для гостей, $\mathrm{y}$ медіапросторі та, найголовніше, для мешканців міста.

\section{Висновки}

У роботі наведено результати інвентаризації деревно-чагарникових насаджень парків i скверів мікрорайону Ужгорода «Малий Галагов».

На теперішній час у межах мікрорайону «Малий Галагов» нараховується дев'ять парків і скверів. Найстарішим парком $\epsilon$ дендросад Лаудона, що був закладений у 1886 р. за часів Австро-угорської імперії. Сім скверів були створені в період входження Закарпаття до складу Чехословацької республіки (1919-1939). Сквер на площі Народній закладено у радянський період.

Парки і сквери мікрорайону займають площу 5,0727 га. Найбільшими за розмірами $\epsilon$ партер на площі Народній та сквер «Малий Галагов».

Загалом сьогодні в парках i скверах мікрорайону «Малий Галагов» зафіксовано 76 деревно-чагарникових видів, що відносяться до 26 родин, загальною кількістю 498 екземплярів. У цілому за видовою та кількісною представленістю переважають у порівнянні 3 голонасінними квіткові рослини $\mathrm{y}$ співвідношенні 1:3. У трьох скверах кількість видів та екземплярів голонасінних рослин більша. Найбільшою видовою насиченістю за співвідношенням «площа - кількість видів» характеризується сад Лаудона.

Інтродуковані види становлять половину від загальної кількості видів рослин, що ростуть у мікрорайоні «Малий Галагов», проте за кількістю екземплярів аборигенні рослини складають всього 1/3.

У всіх парках і скверах, крім скверу «Університетський», за кількістю видів домінують інтродуковані рослини. Майже така ж ситуація і 3 кількістю особин - тільки в скверах «Університетський» та «Малий Галагов» переважають аборигенні рослини.

Щодо походження інтродуцентів, то серед голонасінних переважають північноамериканські види, серед покритонасінних китайсько-японські.

У результаті аналізу життєвого стану зелених насаджень парків і скверів мікрорайону «Малий Галагов» виявлено, що кількість пошкоджених і хворих дерев коливається в межах 7,1-25,4\%. Найбільшою кількістю фаутних дерев характеризується сквер «Малий Галагов». Пошкодження деревної рослинності представлені, в основному, другим та третім класами санітарного стану, тому вчасні заходи щодо захисту та відновлення дерев допоможуть покращити ситуацію. Дерева, які відмирають, виявлено тільки в двох скверах «Університетський» та «Малий Галагов».

Сьогодні всі парки та сквери потребують невідкладних заходів благоустрою, а більшість - термінової реконструкції, зокрема, підсадки дерев, вилучення малоцінних самосівів, упорядкування крон. Одним із першочергових заходів $\epsilon$ фахова розробка проектів ландшафтного дизайну та поетапного плану дій стосовного кожного з парків і скверів. 
BESEHANYCH, I.V., HASYNETS, Ya.S., KISH, R.Ya., SOYMA, A.D., VAKERYCH, M.M. (2020) Derevno-chaharnykovi nasadzhennia mikroraionu «Malyy Galagov» m. Uzhhoroda - istoriia formuvannia ta suchasnyi stan [Tree and shrub plantations of urban district «Malyi Galagov» of Uzhhorod town - the history of formation and current status]. Scientific Bulletin of the Uzhhorod University. Series Biology, 48: 56-71. (in Ukrainian).

BILANYCH, M.M. (2012) Ishtvan Laudon: 150 richchia vid dnia narodzhennia pedahoha, zasnovnyka Uzhhorodskoho dendrariiu (1862-1924). In: Kalendar kraieznavchykh pamiatnykh dat na 2012 rik. Vydavnytsvo V. Padiaka, Uzhhorod, pp. 226230. (in Ukrainian).

BUBRIAK, Y.Y. (1957) Ob itogakh introduktsii i akklimatizatsii rastenij $\mathrm{v}$ botanicheskom sadu Uzhgorodskogo gosudarstvennogo universiteta. Nauchnye zapiski UzhGU. Botanika, XXIII: 109115. (in Russian).

CHERVONA KNYHA UKRAYINY. ROSLYNNYI SVIT (2009) Didukh, Ya.P. (Ed.). Kyiv, Hlobalkonsaltynh, 990 s. (in Ukrainian).

FEDAKA, S. (2010) Uzhhorod kriz viky. Narysy z istoriyi Uzhhoroda. Patent, Uzhhorod. (in Ukrainian).

FODOR, S.S. (1951) K voprosu ob izuchenii ekzotov Zakarpatiya. Naukovi zapysky UzhDU, IV: 69-86. (in Russian).

FODOR, S.S. (1956). Dendroflora Zakarpatja i puti jejo obogashchenija. Dissertatsija na soiskanije uchenoj stepeni kandidata biologycheskikh nauk. Uzhhorod. (in Russian).

FODOR, S.S. (1957) Istorija i puti introduktsii drevesnykh i kustarnikovykh nasazhdenij $\mathrm{v}$ Zakarpatye. Nauchnye zapiski UzhGU. Botanika, XXIII: 167-182. (in Russian).
FODOR, S.S. TERLETSKYI, V.K., HLADUN, Ya.D. (1982) Ekzoty Karpat. Karpaty, Uzhhorod, pp. 120. (in Ukrainian).

HASYNETS, Ya.S., BESEHANYCH, I.V., KISH, R.Ya., SOIMA, A.D., VAKERYCH, M.M. (2017) Dendroflora skveru pl. Shandora Petefi m. Uzhhoroda ta yii suchasnyi stan [Public park dendroflora of Shandor Petefi square of Uzhhorod town and its present state]. Scientific Bulletin of the Uzhhorod University. Series Biology, 42: 94-105. (in Ukrainian).

KOBAL, Y. (2003) Uzhhorod vidomyi i nevidomyi. Svit, Lviv, pp. 196. (in Ukrainian).

KOMENDAR, V.I. (1990) Yak znyshchyty pamiatnyk pryrody. Zakarpatska pravda, 11(14245): 4. (in Ukrainian).

KOMENDAR, V.I. (2005) Iz sokyroiu po zemniy sviatyni, abo Rekviiem po dendrosadu Laudona. Novyny Zakarpattia, 115: 6. (in Ukrainian).

KOMPLEKSNAJA ZELENAJA ZONA UZHGORODA (PROEKT BLAGOUSTROJSTVA I OZELENENIJA) (1982) Uzhhorod. (in Russian).

KUSHNIR, B.H., UGLIAY, A.Y. (1990) Uzhgorod. Ocherk-putevodytel. Karpaty, Uzhhorod. (in Russian).

LITERATI T. (2015) Vtrachenyi Uzhhorod: yak zminiuvalasia ploshcha Narodna. «Pro Zakhid», Available at: https://prozahid.com/content-9657$\mathrm{html} /$ (in Ukrainian).

LYPA, O.L. (1960) Vyznachni sady i parky Ukraiiny. Vydavnytstvo Kyivskoho universytetu, Kyiv. (in Ukrainian).

OLASHYN, O. (2013) Ploshcha Narodna: fakty, mify ta manipuliatsii. Varosh, Available at: https://varosh.com.ua/kultura/ploshha-narodna-faktimifi-ta-manipulyacii/ (in Ukrainian).

TERLETSKYI, V.K., FODOR, S.S., HLADUN, Ya.D. (1985). Botanichni skarbnytsi Karpat. Karpaty, Uzhhorod, pp. 136. (in Ukrainian). 